\title{
Estrogen Receptor $\beta$ Contributes to Both Hypertension and Hypothalamic Plasticity in a Mouse Model of Peri-Menopause
}

\author{
${ }^{\text {D }}$ Teresa A. Milner, ${ }^{1,2}$ Natalina H. Contoreggi, ${ }^{1}$ Fangmin Yu, ${ }^{1}$ Megan A. Johnson, ${ }^{1}$ Gang Wang, ${ }^{1}$ Clara Woods, ${ }^{1}$ \\ Sanoara Mazid, ${ }^{1}$ Tracey A. Van Kempen, ${ }^{1}$ Elizabeth M. Waters, ${ }^{2}$ Bruce S. McEwen, ${ }^{2+}{ }^{\circledR}$ Kenneth S. Korach, ${ }^{3}$ and \\ Michael J. Glass ${ }^{1}$ \\ ${ }^{1}$ Feil Family Brain and Mind Research Institute, Weill Cornell Medicine, New York, New York 10065, ${ }^{2}$ Harold and Milliken Hatch Laboratory of \\ Neuroendocrinology, Rockefeller University, New York, New York 10065, and ${ }^{3}$ Reproductive and Developmental Biology Laboratory, National \\ Institute of Environmental Health Sciences/National Institutes of Health, North Carolina 27709
}

Hypertension susceptibility in women increases at the transition to menopause, termed perimenopause, a state characterized by erratic estrogen fluctuation and extended hormone cycles. Elucidating the role of estrogen signaling in the emergence of hypertension during perimenopause has been hindered by animal models that are confounded by abrupt estrogen cessation or effects of aging. In the present study, accelerated ovarian failure (AOF) in estrogen receptor $\beta(E R \beta)$ reporter mice was induced by 4 -vinylcyclohexene diepoxide in young mice to model early-stage ovarian failure (peri-AOF) characteristic of peri-menopause. It was found that administering ER $\beta$ agonists suppressed elevated blood pressure in a model of neurogenic hypertension induced by angiotensin II (AngII) in peri-AOF, but not in age-matched male mice. It was also found that ER $\beta$ agonist administration in peri-AOF females, but not males, suppressed the heightened NMDAR signaling and reactive oxygen production in ER $\beta$ neurons in the hypothalamic paraventricular nucleus (PVN), a critical neural regulator of blood pressure. It was further shown that deleting ER $\beta$ in the PVN of gonadally intact females produced a phenotype marked by a sensitivity to AngII hypertension. These results suggest that ER $\beta$ signaling in the PVN plays an important role in blood pressure regulation in female mice and contributes to hypertension susceptibility in females at an early stage of ovarian failure comparable to human perimenopause.

Key words: estrogens; hormone replacement; neural plasticity; NMDAR; paraventricular nucleus of the hypothalamus

Significance Statement

In women, altered gonadal hormone signaling is implicated in the increased hypertension incidence associated with perimenopause. However, the role of estrogen signaling in perimenopausal hypertension is not well understood. We demonstrate that cyclic estrogen receptor $\beta(\operatorname{ER} \beta)$ agonist administration reverses hypertension susceptibility in a chemical model of perimenopause. We also show that the reduced hypertension in this model is associated with a suppression of NMDAR signaling in ER $\beta$-expressing hypothalamic paraventricular nucleus neurons in AngII treated-mice. Finally, deleting paraventricular nucleus ER $\beta$ in intact female mice produced a phenotype characterized by sensitivity to AngII hypertension. These results provide preclinical evidence supporting a therapeutic window of opportunity for management of hypertension by $\operatorname{ER} \beta$ agonists as women transition through menopause.

Received Jan. 9, 2021; revised Apr. 21, 2021; accepted Apr. 26, 2021.

Author contributions: T.A.M., G.W., E.M.W., B.S.M., and M.J.G. designed research; T.A.M., N.H.C., F.Y., M.A..., G.W., C.W., S.M., T.A.V.K., and M.J.G. performed research; T.A.M., N.H.C., F.Y., M.A.J., G.W., C.W., S.M., T.A.V.K., E.M.W., and M.J.G. analyzed data; T.A.M., S.M., and M.J.G. wrote the paper; G.W., C.W., T.A.V.K., E.M.W., and K.S.K. edited the paper; B.S.M. wrote the first draft of the paper; K.S.K. contributed unpublished reagents/analytic tools.

This work was supported by National Institutes of Health Grants HL36520, HL098351, and HL135498; and Division of Intramural Research, National Institute of Environmental Health Sciences/National Institutes of Health research support 1ZIAES070065 to K.S.K. This work is dedicated to Dr. Bruce S. McEwen (deceased Jan. 2, 2020).

'Deceased Jan. 2, 2020.

E.M. Waters' present address: The Cooper Union, 41 Cooper Sq, New York, NY 10003.

The authors declare no competing financial interests.

Correspondence should be addressed to Teresa A. Milner at tmilner@med.cornell.edu or Michael J. Glass at mjg2003@med.cornell.edu.

https://doi.org/10.1523/JNEUROSCI.0164-21.2021

Copyright $\odot 2021$ the authors

\section{Introduction}

Hypertension is a major modifiable risk factor for cerebral, cardiovascular, and other diseases (Sylvester and Brooks, 2019). Significantly, there is a marked sexual dimorphism in both the incidence and health impacts of hypertension. For example, hypertensive women show more severe pathophysiological outcomes compared with hypertensive men (Wenger, 2020). Additionally, the risk of hypertension in women varies at distinct life phases (Wenger et al., 2018). In particular, the onset of menopause is a critical period that is associated with increasing hypertension risk that may be uniquely sensitive to therapeutic intervention by gonadal hormone replacement. Indeed, in recent 
years, medical organizations, such as the Endocrine Society (Stuenkel et al., 2015) and the North American Menopause Society (2017), have begun recommending the benefits of hormone replacement therapy to reduce the symptoms of menopause specifically in women under the age of 60 or $<10$ years postmenopause who also have a moderate risk or less of cardiovascular disease. Despite the increasing recognition of perimenopause as a therapeutic window of opportunity (Pinkerton and Stovall, 2010; Hodis and Mack, 2011), the mechanisms subserving the emerging hypertension risk at this menopausal stage are unknown.

Changes in ovarian hormones, including irregular cycles and erratically fluctuating estrogen levels (Harsh et al., 2007; Nejat and Chervenak, 2010) arising at the perimenopausal stage, have been associated with an increase in blood pressure and sympathetic tone (Rosano et al., 2007). However, the mechanisms by which alterations in estrogen contribute to hypertension are not well understood. Unfortunately, conventional animal models relying on ovariectomy or aging do not adequately capture the gradual patterns of ovarian hormone changes seen in human perimenopause, complicating the experimental study of estrogen and hypertension in females during ovarian decline. In particular, ovariectomy resembles surgical menopause and results in the abrupt depletion of estrogen as well as other ovarian hormones (Van Kempen et al., 2011; Marques-Lopes et al., 2018). Moreover, although the natural aging model of menopause results in acyclicity seen in postmenopause, the estrogen levels are not completely depleted; and it is difficult to disentangle aging from hormonal effects (Marques-Lopes et al., 2018). The model of accelerated ovarian failure (AOF) in rodents using administration of 4-vinylcyclohexene diepoxide (VCD) uniquely recapitulates erratic estrogen fluctuations and extended hormone cycles seen in human menopause and better mimics the perimenopause stage, which we term "peri-AOF," in rodent species (Van Kempen et al., 2011, 2014; Brooks et al., 2016; MarquesLopes et al., 2018). Using this model, we have shown that the susceptibility to slow-pressor angiotensin II (AngII)-induced hypertension in mice begins at peri-AOF and extends into post-AOF (Marques-Lopes et al., 2017).

Estrogen signaling in the hypothalamic paraventricular nucleus (PVN), a key neural component of cardiovascular regulatory circuitry, has been shown to contribute to blood pressure regulation (for review, see Van Kempen et al., 2016). Estrogen receptor $\beta(\operatorname{ER} \beta)$ is a predominant estrogen receptor in the PVN (Van Kempen et al., 2016; Contoreggi et al., 2021). In addition to its established transcriptional effects, estrogen acting at $\operatorname{ER} \beta$ is known to modulate fast NMDAR-mediated excitatory signaling (Sellers et al., 2015). This is significant given the important role of NMDAR plasticity in the hypothalamus during AngIIinduced hypertension in males (Glass et al., 2015; Reckelhoff et al., 2019; Woods et al., 2021). Estrogen is also known to modulate levels of reactive oxygen species (ROS), which are elevated during menopause (Zitnõanová et al., 2011) and are also implicated in hypertension-associated increases in NMDAR signaling in the PVN (Wang et al., 2013). However, little is known about the role of $\mathrm{ER} \beta$ in NMDAR activation and ROS production in the PVN in peri-AOF hypertension. Here we examine the effect of $\operatorname{ER} \beta$ agonist administration on slow-pressor AngII-induced hypertension in peri-AOF females compared with age-matched males. We also assess the role of ER $\beta$ in NMDAR signaling and blood pressure using high-resolution electron microscopy (EM), whole-cell patch-clamping, in situ microfluorography, spatialtemporal gene deletion, and blood pressure measurement.

\section{Materials and Methods}

All procedures were approved by the Institutional Animal Care and Use Committee of Weill Cornell Medicine and were in accordance with the 2011 Eighth Edition of the National Institutes of Health's Guide for the care and use of laboratory animals.

\section{Animals}

Three strains of adult mice were used: (1) WT C57BL/6J mice; (2) bacterial artificial chromosome ER $\beta$-EGFP reporter mice (Milner et al., 2010) originally obtained from Rockefeller University; and (3) floxed $\operatorname{ER} \beta$ (fER $\beta$ ) mice (Burns et al., 2012; Binder et al., 2013) (all bred in house). ER $\beta$-EGFP reporter mice were bred on an FVB/N background, backcrossed with WT C57BL/6 mice for 6 generations, and then crossed with each other until a homozygotic phenotype was achieved. The GFP genotype was verified using a real-time PCR genotyping service (Transnetyx). The fidelity of the ER $\beta$-EGFP mice has been previously established (Milner et al., 2010). In the fER $\beta$ mice, loxP sites flank exon 3 sequences of the $\operatorname{ER} \beta$ gene that code for the essential first zinc finger of the DNA-binding domain critical for the function of steroid receptors (Burns et al., 2012; Binder et al., 2013). After Cre recombinase-mediated cleavage of loxP sites, cells are incapable of synthesizing normal ER $\beta$ (Burns et al., 2012; Binder et al., 2013). Mice were housed in groups of 3 or 4 per cage with a $12 \mathrm{~h}$ light/ $12 \mathrm{~h}$ dark cycle and ad libitum access to food and water.

For most studies, the female and male mice from each strain were littermates; otherwise, the mice were age-matched from the same colony. Female and male mice were randomly assigned to experimental groups. To minimize stress, the mice in each cohort were handled by the same experimenters and at the same time of day throughout the study.

At the termination of experiments, estrous phases were determined using vaginal smear cytology (Turner and Bagnara, 1971) after the mice were anesthetized. The estrous cycle was classified into three primary phases: (1) proestrus (high estrogen levels; 0.5-1 d long), (2) estrus (declining estrogen levels and increasing progesterone levels; $2-2.5 \mathrm{~d}$ long), and (3) diestrus (low estrogen and progesterone levels; $2-2.5 \mathrm{~d}$ long).

\section{AOF model of perimenopause}

AOF was induced in female mice using the VCD mouse model (Van Kempen et al., 2011, 2014). Previous studies have shown that AOF using VCD in mice successfully recapitulates the gradual time course of hormonal changes seen from perimenopause to postmenopause phases in humans (for review, see Van Kempen et al., 2011; Marques-Lopes et al., 2018). An advantage of the AOF model is that it can separate hormonal effects from aging effects (Van Kempen et al., 2011; Brooks et al., 2016; Marques-Lopes et al., 2018). Low-dose injections of VCD selectively eliminate the primary follicles of the ovary and do not negatively affect peripheral tissues, organ weights, and liver and kidney function (Haas et al., 2007; Sahambi et al., 2008; Wright et al., 2008; Brooks et al., 2016). VCD does not increase inflammation markers in the brain, including the PVN (Van Kempen et al., 2014).

To induce AOF, gonadally intact 50- to 55-postnatal-day-old female mice were injected with VCD $(130 \mathrm{mg} / \mathrm{kg}$ in sesame oil, i.p.; catalog \#S453005, Millipore Sigma) in sesame oil (catalog \#8008-74-0, Millipore Sigma) for 5 sequential days per week for 3 weeks (Van Kempen et al., 2011; Marques-Lopes et al., 2017). A schematic timeline for the VCD injection procedure is provided in Figure $1 A$. The time point corresponding to the peri-AOF stage following VCD injections was determined previously (Lohff et al., 2005; Haas et al., 2007; Van Kempen et al., 2014). At the peri-AOF phase (58 d after first VCD injection) used in this study, the mice are $\sim 3.5$ months old and have irregular and extended estrous cycles paralleled by elevated plasma follicle stimulating hormone (Mayer et al., 2004; Lohff et al., 2005; Harsh et al., 2007). At peri-AOF, $\sim 50 \%$ of the mice have a normal cyclicity (Van Kempen et al., 2014).

\section{Slow-pressor AngII induction}

Prior studies have established that a sex-specific susceptibility to hypertension is recapitulated in mice following systemic administration of low doses of AngII. This "slow pressor" AngII infusion induces an increase 
A
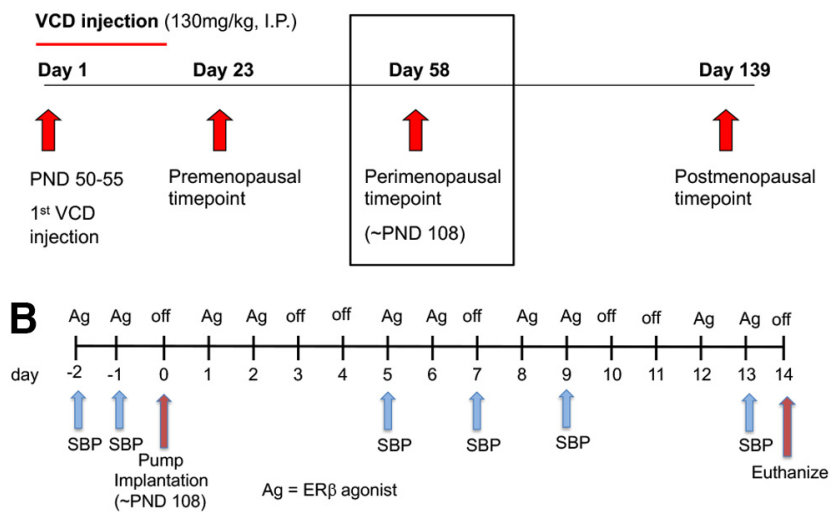

Figure 1. Schematic timelines of $A O F$ induction in female mice and slow-pressor Angll infusion with coinciding cyclic $\operatorname{ER} \beta$ replacement regimen. $\boldsymbol{A}$, Female mice were injected with VCD $(130 \mathrm{mg} / \mathrm{kg}$, i.p.) for 3 weeks, $5 \mathrm{~d}$ per week, starting between postnatal day (PND50-55). Mice are considered peri-AOF starting $58 \mathrm{~d}$ after VCD injection (black box, $\sim$ PND 108 or $\sim 3.5$ months old). $B$, Female mice at the peri-AOF time point and agedmatched males were implanted with osmotic mini-pumps containing Angll $\left(600 \mathrm{ng} / \mathrm{kg}^{-1} /\right.$ $\mathrm{min}^{-1}$ ) or Sal (saline $+0.1 \% \mathrm{BSA}$ ) for $14 \mathrm{~d}$. SBP was measured with tail-cuff plethysmography before (baseline) and 5, 7, 9, and $13 \mathrm{~d}$ after mini-pump implantation. The $\operatorname{ER} \beta$ agonist (Ag) replacement (DPN $1 \mathrm{mg} / \mathrm{kg}$, ERBO41 $1 \mathrm{mg} / \mathrm{kg}$, or LQG $10 \mathrm{mg} / \mathrm{kg}$ ) regimen was initiated $2 \mathrm{~d}$ before the mini-pump insertions and continued every $2-3 \mathrm{~d}$ until the mice were killed.

in sympathetic tone and blood pressure in young male mice, but not young female mice (Xue et al., 2005; Girouard et al., 2009; Tiwari et al., 2009; Marques-Lopes et al., 2014, 2015, 2017; Van Kempen et al., 2015). However, slow pressor AngII induces hypertension in ovariectomized females (Xue et al., 2013; Hay et al., 2014), aged females (Tiwari et al., 2009; Marques-Lopes et al., 2014), and peri- and post-AOF female mice (Marques-Lopes et al., 2017; Ovalles et al., 2019).

A schematic timeline of the implantation and systolic blood pressure $(\mathrm{SBP})$ readings is provided in Figure $1 B$. Mice were acclimated to the room and instrumentation for 1 week before baseline SBP readings (see below) before implantation of mini-pumps. Under isoflurane anesthesia, osmotic mini-pumps (Alzet, Durect) containing vehicle (saline $+0.1 \%$ BSA, catalog \#A7030, Millipore Sigma), which is referred to as saline (Sal) or AngII (600 ng $\cdot \mathrm{kg}^{-1} \cdot \mathrm{min}^{-1}$; catalog \#A9525, Millipore Sigma) dissolved in vehicle were implanted subcutaneously. Mini-pumps were implanted in females $58 \mathrm{~d}$ after the first VCD injection (peri-AOF) and in age-matched males $(\sim 3.5$ months old). SBP was measured before (baseline), and 5, 7, 9, and $13 \mathrm{~d}$ after mini-pump implantation in awake mice by tail-cuff plethysmography (model MC4000; Hatteras Instruments), as described previously (Coleman et al., 2010). Tail-cuff plethysmography is a reliable method for comparing SBP between groups (Capone et al., 2010; Coleman et al., 2010; Wang et al., 2013; Marques-Lopes et al., 2014, 2015); the limitations of this method to measure blood pressure have been discussed previously (Marques-Lopes et al., 2014). As electron microscopic methods require aortic arch perfusion fixation (Milner et al., 2011), tail-cuff plethysmography is necessary as it is noninvasive and does not compromise the carotid artery, unlike telemetric blood pressure recording in mice (Butz and Davisson, 2001). Moreover, tail-cuff methodology does not necessitate single-housing, which can increase stress (N. Liu et al., 2020). Prior studies showing elevations in SBP following slow pressor AngII using tail-cuff plethysmography are consistent with those using telemetry (Capone et al., 2011; Glass et al., 2015). To control for handling effects, mice were killed $1 \mathrm{~d}$ after the final SBP measurements (i.e., $14 \mathrm{~d}$ after pump implantation) (Coleman et al., 2013; Wang et al., 2013; Marques-Lopes et al, 2014, 2015).

ER $\beta$ agonist selection and cyclic replacement regimen

As three classes of $\operatorname{ER} \beta$ agonists have been identified (Leitman et al., 2010), one compound from each class was subcutaneously administered in this investigation. Diarylpropionitrile (DPN) is an $\operatorname{ER} \beta$ "binder/activator" that binds $\mathrm{ER} \beta$ with high affinity and is a more potent activator of $\mathrm{ER} \beta$ than $\mathrm{ER} \alpha$. ERB-041 (prinaberel) is a "binder" as it has a $>200$ fold selectivity for $\mathrm{ER} \beta$ than $\mathrm{ER} \alpha$ (Harris et al., 2003). Liquiritigenin (LQG), a major active compound of MF101 (Kupfer et al., 2008), is an "activator"; although it binds $\operatorname{ER} \beta$ and $\operatorname{ER} \alpha$ similarly, it only activates ER $\beta$ (Cvoro et al., 2007; Mersereau et al., 2008).

For each respective agonist, we selected the lowest dose previously shown to produce a physiological response. For DPN (catalog \#1494, Tocris Bioscience), $1 \mathrm{mg} / \mathrm{kg}$ was used as this dose increases spine lengths, synaptic proteins, and glutamate receptors in the hippocampus of mice and rats (Waters et al., 2009; Phan et al., 2011) and reduces anxiety behaviors in mice (Oyola et al., 2012). For ERB-041 (catalog \#4276, Tocris Bioscience), $1 \mathrm{mg} / \mathrm{kg}$ was chosen as this dose has a beneficial effect in rat models of inflammatory bowel disease and arthritis (Harris et al., 2003). For LQG (catalog \#3819, Tocris Bioscience), $10 \mathrm{mg} / \mathrm{kg}$ was chosen as this dose attenuates learning and memory deficits in transgenic mouse models of Alzheimer's disease (R. T. Liu et al., 2011).

A schematic timeline of the ER $\beta$ regimen, coinciding with AngII induction and SBP readings is provided in Figure $1 B$. A cyclical agonist administration regimen was chosen as it replicates the pulsatile nature of estrogen levels that is more physiologically relevant than daily hormone exposure (Morrison et al., 2006). Mice were "primed" with a daily dose of an agonist $2 \mathrm{~d}$ before mini-pump implantation and then injected with agonist every $2-3 \mathrm{~d}$ for a total of 10 injections.

\section{Antibodies}

ER $\beta$. A rabbit antibody to ER $\beta$ (Z8P; discontinued; Zymed Laboratories) was used to quantify ER $\beta$-labeled nuclei in the PVN of fER $\beta$ mice. The specificity of this antibody was previously shown by (1) dual-labeling with mRNA using ISH, (2) preadsorption control, and (3) absence of labeling in brain sections from $\operatorname{ER} \beta$ KO mice (Shughrue and Merchenthaler, 2001).

GFP. To label the gene product of EGFP-expressing transgenic mice, a chicken polyclonal anti-GFP antibody (GFP-1020; RRID:AB 10000240; Aves Lab) was used. This antibody was generated against recombinant GFP, and specificity has been demonstrated by positive labeling via immunohistochemistry and Western blot in transgenic mice expressing EGFP (see data sheet for EGFP-1020; www.aveslab.com). Additionally, the absence of labeling has been shown in brain sections from mice not expressing EGFP (Volkmann et al., 2010; Milner et al., 2011).

GluN1. To identify GluN1 (the NMDAR 1 protein encoded by the Grin1 gene), a monoclonal mouse anti-GluN1 antibody (clone 54.1; RRID:AB_86917; BD Biosciences) was used. Specificity of the GluN1 antibody was demonstrated via immunoprecipitation and affirmative labeling in immunohistochemistry (Brose et al., 1994; Siegel et al., 1994). Reduced labeling has been shown following rAAV-Cre administration into the brain of floxed GluN1 mice (Beckerman and Glass, 2012). Further specificity was shown via Western blot analysis of rat synaptic membranes and monkey hippocampal homogenates, resulting in one major band at $116 \mathrm{kDa}$. Additionally, HEK 293 cells transfected with cDNA encoding GluN1 displayed similar band results, whereas nontransfected cells resulted in no bands (Siegel et al., 1994).

\section{Dual-labeling EM}

Section preparation. Using previously described methods (Milner et al., 2011), four groups of ER $\beta$ reporter mice were prepared for EM: (1) AngII/Vehicle (Veh) VCD females; (2) AngII/DPN VCD females; (3) AngII/Veh males; and (4) AngII/DPN males. Mice were deeply anesthetized with sodium pentobarbital $(150 \mathrm{mg} / \mathrm{kg}$, i.p.) and their brains fixed by aortic arch perfusion with $3.75 \%$ acrolein (Polysciences) and 2\% PFA (Electron Microscopy Sciences) in $0.1 \mathrm{M} \mathrm{PB}, \mathrm{pH} 7.4$, as described previously (Milner et al., 2011). After the perfusion, brains were removed and postfixed for $30 \mathrm{~min}$ in $2 \%$ acrolein and $2 \%$ PFA in PB at room temperature. Brains were then cut into $5 \mathrm{~mm}$ coronal blocks using a brain mold (Activational Systems) and coronal sections ( $40 \mu \mathrm{m}$ thick) through the PVN were cut on a Vibratome (VT1000X; Leica Microsystems) and then stored at $-20^{\circ} \mathrm{C}$ in cryoprotectant $(30 \%$ sucrose, $30 \%$ ethylene glycol in 
PB) until immunocytochemical processing. To ensure identical labeling conditions between experimental groups (Pierce et al., 1999), two sections per animal encompassing the region of the PVN $(0.70-0.94 \mathrm{~mm}$ bregma) (Hof et al., 2000) were marked with identifying punches, pooled into single containers, and then processed together through all immunocytochemical procedures.

Immunocytochemical procedures and tissue processing for EM. Freefloating PVN sections were dually labeled for GFP (to identify ER $\beta$ EGFP) and GluN1 using previously described methods (Milner et al., 2011). Sections were rinsed in PB to remove cryoprotectant followed by incubation in $1 \%$ sodium borohydride in PB for $30 \mathrm{~min}$ to remove excessive aldehydes. Sections were washed 8-10 times in PB until no gaseous bubbles were visible and then were rinsed in $0.1 \mathrm{~m}$ Tris-buffered saline (TBS; pH 7.6). Next, sections were incubated sequentially as follows: (1) $0.5 \%$ BSA in TBS, $30 \mathrm{~min}$; (2) a primary antisera cocktail of chicken antiGFP (1:3000) and mouse anti-GluN1 (1:50) in $0.1 \%$ BSA for $1 \mathrm{~d}$ at room temperature $\left(\sim 23^{\circ} \mathrm{C}\right)$, followed by $2 \mathrm{~d}$ in cold $\left(\sim 4^{\circ} \mathrm{C}\right)$; (3) $1: 400$ dilution of donkey anti-chicken biotinylated IgG (catalog \#703-065-155; Jackson ImmunoResearch Laboratories), $30 \mathrm{~min}$; (4) avidin-biotin complex (Vectastain Elite Kit, Vector Laboratories) at half the manufacturer's recommended dilution in TBS, $30 \mathrm{~min}$; and (5) DAB (Millipore Sigma) and $\mathrm{H}_{2} \mathrm{O}_{2}$ in TBS for $3 \mathrm{~min}$. All incubations were separated by washes of TBS.

For immunogold labeling of GluN1, forebrain tissue was incubated in a 1:50 dilution of goat anti-mouse IgG conjugated to $1 \mathrm{~nm}$ gold particles (catalog \#25120 Electron Microscopy Sciences) in $0.01 \%$ gelatin and $0.08 \% \mathrm{BSA}$ in $0.01 \mathrm{M}$ PBS for $24 \mathrm{~h}$ at $4^{\circ} \mathrm{C}$. Sections then were rinsed in PBS and postfixed in $2 \%$ glutaraldehyde in PBS for $10 \mathrm{~min}$. After rinsing in PBS, sections were placed in $0.2 \mathrm{~m}$ sodium citrate buffer, $\mathrm{pH}$ 7.4. Bound gold particles were enhanced with silver solution (SEKL15 Silver enhancement kit, product \#15718 Ted Pella) for $\sim 7 \mathrm{~min}$.

Dual-labeled sections were postfixed for $1 \mathrm{~h}$ in $2 \%$ osmium tetroxide in $\mathrm{PB}$, dehydrated through a series of alcohols and propylene oxide, and embedded in EMBed 812 (Electron Microscopy Sciences) between two sheets of Aclar plastic (Milner et al., 2011). Ultrathin sections $(\sim 70 \mathrm{~nm}$ thick) through the PVN were cut with a diamond knife (Electron Microscopy Sciences) on a Leica UCT ultratome. Sections were collected on 400-mesh thin-bar copper grids (T400-Cu, Electron Microscopy Sciences) and counterstained with Uranyless (catalog \#22409, Electron Microscopy Sciences) and lead citrate (catalog \#22410, Electron Microscopy Sciences).

Data collection and image analysis. Ultrathin forebrain sections containing the PVN were analyzed on a Tecnai Biotwin transmission electron microscope (FEI, Hillsboro), and images were acquired with a digital camera system (version 3.2, Advanced Microscopy Techniques). Images were captured at a magnification of $13,500 \times$ and profiles identified based on standard morphologic criteria (Peters et al., 1991). Dendrites were usually between 0.5 and $2.0 \mu \mathrm{m}$ in cross-sectional diameter and were postsynaptic to axon terminals which contained numerous small synaptic vesicles. Immunoperoxidase precipitate within GFP-labeled dendrites was diffuse and granular, whereas SIG labeling for GluN1 appeared as black electron-dense particles (Milner et al., 2011). Micrographs were collected and analyzed by investigators who were blind to experimental conditions until after the final data analysis and statistics were performed.

A total of 50 randomly selected micrographs of dually labeled dendritic profiles for each mouse were taken to ensure unbiased sampling of different dendritic regions. The location of the micrographs collected were noted on a low-magnification photograph of the block surface so that samples were not double counted. Usually, one ultrathin-section per block yielded the required number of dendrites but sometimes dendritic images from a nonoverlapping region of a second section were collected. Three mice per experimental group were analyzed yielding 150 dendrites per group for the statistical analysis.

Microcomputer Imaging Device software (MCID Imaging Research; RRID:SCR_014278) was used to determine perimeter (i.e., plasma membrane), cross-sectional area, average diameter, and major and minor axis lengths for all dendrites. Average diameter measures were used to normalize SIG counts per unit measure of dendrites (see below) and to classify dendrites as large (diameter $>1.0 \mu \mathrm{m}$; i.e., proximal) or small (diameter between 0.4 and $1.0 \mu \mathrm{m}$; i.e., distal). The location of GluN1SIG particles (on plasmalemma, near plasmalemma or within the cytoplasm) for each dendritic profile also was noted. Next, the density of GluN1-SIG particles in dendrites was calculated for the following: (1) the number of plasma membrane GluN1-SIG particles on the dendrite perimeter $(\mathrm{On} \mathrm{PM} / \mu \mathrm{m})$; (2) the number of near plasma membrane $(<70 \mathrm{~nm})$ GluN1-SIG particles per perimeter $(\mathrm{Near} / \mu \mathrm{m})$; (3) the number of cytoplasmic GluN1-SIG particles per cross-sectional area (Cyto/ $\mu \mathrm{m}^{2}$ ); and (4) the total number of GluN1-SIG particles (sum of on PM, near PM and cytoplasmic) in a dendritic profile/unit area (Total $/ \mu \mathrm{m}^{2}$ ).

The location of GluN1-SIG particles within dendrites has functional significance. In response to agonist stimulation, the ratio of plasmalemma-to-cytoplasmic SIG labeled receptors shows the expected decrease (Haberstock-Debic et al., 2003); thus, the presence of plasma membrane receptors identified by SIGs corresponds to sites of receptor binding (Boudin et al., 1998). Near plasma membrane receptors comprise a pool from which receptors can be added or removed from the plasma membrane. SIGs in the cytoplasm represent receptors that are being recycled, stored, and/or transported between the soma or another cellular compartment, or degraded (Pierce et al., 2009; FernandezMonreal et al., 2012).

\section{Whole-cell NMDA-induced currents}

NMDA-mediated currents were measured in PVN neurons from brain slices, similar to previous studies (Girouard et al., 2009; Coleman et al., 2013; Woods et al., 2021). Coronal slices containing the PVN $(200 \mu \mathrm{m}$ thick, cut on Vibratome) were first immersed in lactic aCSF (1-aCSF; pH 7.4) with $95 \% \mathrm{O}_{2}$ and $5 \% \mathrm{CO}_{2}$ at $32^{\circ} \mathrm{C}$ for $1 \mathrm{~h}$ and then gassed with $1-$ aCSF in a glass-bottom chamber $(2 \mathrm{ml} / \mathrm{min})$ continuously. The 1-aCSF was composed of (in mmol/L): $124 \mathrm{NaCl}, 26 \mathrm{NaHCO}_{3}, 5 \mathrm{KCl}, 1$ $\mathrm{NaH}_{2} \mathrm{PO}_{4}, 2 \mathrm{MgSO}_{4}, 2 \mathrm{CaCl}_{2}, 10$ glucose, 4.5 lactic acid, 95\% $\mathrm{O}_{2}$ and $5 \%$ $\mathrm{CO}_{2}$. The PVN was identified using the fornix, third ventricle, and optic chiasm as a guide (Hof et al., 2000). In slices from ER $\beta$-reporter mice, EGFP-labeled neurons were identified using an E600 epifluorescence microscope (Nikon) with an FITC filter and differential interference contrast optics as described previously (Girouard et al., 2009; Coleman et al., 2013). Cells were patch-clamped using an Axopatch 200B amplifier (Molecular Devices). As NMDAR channels are largely blocked by magnesium $\left(\mathrm{Mg}^{2+}\right)$ ions at resting membrane potentials (Mayer et al., 1984), slices were superfused with $\mathrm{Mg}^{2+}$-free l-aCSF (in mmol/L $121 \mathrm{NaCl}, 5$ $\mathrm{KCl}, 1.8 \mathrm{CaCl}_{2}, 0.01$ glycine, 1 Na-pyruvate, 20 glucose, $26 \mathrm{NaHCO}_{3}, 1$ $\mathrm{NaH}_{2} \mathrm{PO}_{4}, 4.5$ lactic acid, $95 \% \mathrm{O}_{2}$ and $5 \% \mathrm{CO}_{2}, \mathrm{pH} 7.4$ ) to elicit maximal NMDAR-mediated spontaneous firing and inward ionic currents before recordings. Voltage-gated sodium channels and non-NMDAR channels were blocked with $1 \mu \mathrm{mol} / \mathrm{L}$ of TTX (Millipore Sigma) and $5 \mu \mathrm{mol} / \mathrm{L}$ of CNQX (AMPA/kainate receptor antagonist; Millipore Sigma). A Giga $\Omega$ seal was formed using a patch-pipette tip with a resistance of 5-8 $\mathrm{M} \Omega$ and filled with the K-gluconate pipette solution (in mmol/L: $130 \mathrm{~K}$-gluconate; $10 \mathrm{NaCl}, 1.6 \mathrm{MgCl}_{2}$, 1 EGTA, 10 HEPES, $2 \mathrm{Mg}$-ATP, pH 7.3). The patch membrane was broken, and cell membrane capacitance and series resistance were read using Membrane Test of Window pClamp 8.2 (Axon Instruments). To induce NMDA-mediated currents, the cells were superfused with vehicle-containing buffers until a stable baseline current at the holding potential of $-60 \mathrm{mV}$ was reached and then followed by perfusion of NMDA $(30 \mu \mathrm{mol} / \mathrm{L}$; catalog \#M3262, Millipore Sigma) containing $\mathrm{Mg}^{2+}$-free extracellular solution toward the patched neurons for $30 \mathrm{~s}$ (Suh et al., 2010; Coleman et al., 2013). Signals were low-pass filtered at $2 \mathrm{kHz}$ and acquired at a sampling rate of $5-10 \mathrm{kHz}$. Vehicle, the $\operatorname{ER} \beta$ agonist DPN (Tocris Bioscience) at $10 \mu \mathrm{m}$ (Wang et al., 2006), or the ER $\beta$ antagonist 4-[2-phenyl-5,7-bis(trifluoromethyl) pyrazolo[1,5-a]pyrimidin-3-yl]phenol (PHTPP; catalog \#SML 1355 Tocris Bioscience) at $1 \mu \mathrm{M}$ was applied extracellularly (Compton et al., 2004).

In situ microfluorography

Production of ROS in PVN neurons was detected using dihydroethidium (DHE; Invitrogen), a membrane-permeable indicator that fluoresces bright red when oxidized to ethidium by superoxide (Zhao et al., 
2003, 2005). ROS-activated ethidium intercalates with DNA providing the ability to identify the cellular source of oxidative stress (Wang et al., 2013). PVN cells from WT and ER $\beta$-EGFP reporter mice were dissociated as previously described (Girouard et al., 2009; Coleman et al., 2013) and incubated in DHE $(2 \mu \mathrm{M})$ containing oxygenated l-aCSF for $30 \mathrm{~min}$. Time-resolved fluorescence was measured at 1 min intervals with an exposure time of $150 \mathrm{~ms}$ for $40 \mathrm{~min}$ using an ethidium bromide filter (610 nm emit; $270-285$ absorption), a CCD digital camera on a Nikon Diaphot 300 inverted microscope (Princeton Instruments), and IPlab software (RRID:SCR_002775, Scanalytics). As NMDA is known to induce nitric oxide-dependent free radical production in the brain (Girouard et al., 2009), ROS signal was induced by NMDA (100 $\mu \mathrm{M})$ bath immersion for $10 \mathrm{~min}$. Measured baseline background intensity was subtracted from the detected ethidium signal in the NMDA-treated cells. A calculated percent change as "fluorescence after NMDA/baseline fluorescence" within each neuron was used to determine relative ROS production (Gingerich and Krukoff, 2006; Girouard et al., 2009; Marques-Lopes et al., 2015).

NMDA $(100 \mu \mathrm{M})$ induced ROS production following $\operatorname{ER} \beta$ blockade also was measured. An additional study on AngII administered to young female mice was performed using gp91-ds peptide ( $1 \mu \mathrm{M}$, catalog \#AS63818; Anaspec), the main subunit of NOX2 and one of the 4 units required to synthesize ROS (Bedard and Krause, 2007), and its scrambled peptide ( $1 \mu \mathrm{M}$, catalog \#AS-63855; Anaspec) to confirm that the source of the measured superoxide production was from NOX2.

\section{Spatiotemporal deletion of ER $\beta$}

Targeted deletion of the ER $\beta$ gene in the PVN was achieved using stereotaxic procedures for intracranial viral vector microinjection as previously described (Glass et al., 2008, 2015). A specially engineered nonpathogenic recombinant neurotropic serotype 2 adreno-associated virus ( $\mathrm{rAAV} ; \sim 4.7 \mathrm{~kb}$ ) that expresses a fusion protein of Cre and a reporter, GFP (rAAV-Cre) was used (South et al., 2003; Woods et al., 2021). The vector includes a CMV promoter/enhancer, a multiple cloning site for insertion of the GFP-Cre coding sequences, and poly A sequences (South et al., 2003). The control vector (rAAV-GFP) does not express Cre.

Under isoflurane anesthesia ( $4 \%$ induction and $2 \%$ maintenance), $\mathrm{fER} \beta$ female and male mice were stereotaxically microinjected with either rAAV-Cre or rAAV-GFP $\left(100-150 \mathrm{nl} ; 1 \times 10^{12}\right.$ viral particles/ $\left.\mu \mathrm{l}\right)$ into the PVN $(0.8 \mathrm{~mm}$ posterior, $0.2 \mathrm{~mm}$ lateral, and $4.8 \mathrm{~mm}$ ventral to bregma) (Paxinos and Franklin, 2001). SBP measurements were initiated $21 \mathrm{~d}$ after the vector injection. Thirty days after vector injection, mice were implanted with osmotic mini-pumps filled with AngII as described above.

Light microscopic verification of GFP expression and ER $\beta$-deletion following $P V N$ vector microinjection

Following PVN vector microinjection and blood pressure recording, brains were collected for verification of injection sites (Glass et al., 2015; Woods et al., 2021) and quantification of $\operatorname{ER} \beta$-expression in PVN.

Section preparation. Mice were anesthetized with sodium pentobarbital (150 mg/kg, i.p.) and perfused through the aorta with $\sim 5 \mathrm{ml} 2 \%$ heparin in saline followed by $30 \mathrm{ml} 4 \%$ PFA in $0.1 \mathrm{M}$ PB. Coronal sections $(40 \mu \mathrm{m}$ thick) through the PVN were cut on a Vibratome (VT1000X) and then stored at $-20^{\circ} \mathrm{C}$ in cryoprotectant (Milner et al., 2011) until immunocytochemical processing.

Verification of microinjection sites. PVN sections from rAAV-Cre and rAAV-GFP-injected mice were mounted on $1 \%$ gelatin-coated slides and coverslipped with DPX (catalog \#06522; Millipore Sigma).

Labeling of ER $\beta$ cells. Sections were marked with identifying punches, pooled into single containers, and then processed together through all immunocytochemical procedures. Free-floating sections were processed for $A B C$ labeling of the rabbit anti-ER $\beta$ (1:1000 dilution; Zymed) as described in the EM experiments above, except that a goat anti-rabbit biotinylated IgG (catalog \#111-065-144, Jackson ImmunoResearch Laboratories) was used. Slides were dehydrated and coverslipped with DPX.
Nissl staining. PVN sections were mounted on slides and stained with thionin and coverslipped with DPX.

Analysis. Sections were viewed and photographed with a Nikon Eclipse 80i microscope and photographed using a Micropublisher 5.0 digital camera (Q-imaging) and IP Lab software (Scanalytics IPLab, RRID:SCR_002775). In mice receiving a unilateral injection, ER $\beta$-labeled neurons were counted in one mediocaudal PVN section from both the ipsilateral and contralateral sides of the injection. The ratio of ER $\beta$ labeled nuclei in the ipsilateral side compared with the contralateral side of the PVN was determined. Nissl-stained cells were counted in one mediocaudal PVN section from both the ipsilateral and contralateral sides of the injection. The ratio of Nissl cells in the ipsilateral side compared with the contralateral side of the PVN was determined. In mice receiving bilateral injections, $\operatorname{ER} \beta$-containing neurons were counted on both sides on the PVN in one mediocaudal section from rAAV-Cre and control mice.

\section{Figure preparation}

Images were adjusted for brightness, contrast, sharpness, and colorblind friendly palette in Adobe Photoshop 2020 (RRID:SCR_014199). Images then were imported into Microsoft PowerPoint (version 16.16.18, 200112) where final adjustments to sharpness, brightness, and contrast were made. These adjustments did not alter the original content of the raw image and were made to achieve a uniform appearance between micrographs. Graphs were generated in Prism 8 (GraphPad Prism; RRID:SCR_002798).

\section{Experimental design and statistical analysis}

Measurement of SBP in AngII-infused mice with ER $\beta$ agonist replacement. Four groups of mice were prepared: (1) Sal infused VCD females; (2) AngII-infused VCD females; (3) Sal-infused males; and (4) AngII infused males ( $N=15-30 /$ group). Each group received injections of Veh (sesame oil), DPN, ERB-041, or LQG every 2-3 d throughout the $14 \mathrm{~d}$ period of the infusion. Measurement of SBP in each group was compared by repeated-measures ANOVA followed by Tukey post hoc tests for multiple comparisons between groups. In this and all other experiments, data are expressed as mean \pm SEM. All statistical analyses were conducted on JMP 12 Pro software (JMP, RRID:SCR_014242), and significance was set to an $\alpha$ of $<0.05$. The majority of female mice were in estrus or diestrus on the day of death. However, since no estrous cycle-dependent differences were seen in the data, female mice from different estrous stages were pooled in each experiment.

$E M$ analysis of GluN1 distribution in dendrites of ER $\beta$-expressing neurons. Four groups of ER $\beta$ reporter mice were prepared for KO: (1) AngII/Veh VCD females; (2) AngII/DPN VCD females; (3) AngII/Veh males; and (4) AngII/DPN males ( $N=3 /$ group). Relative changes in the subcellular distribution of GluN1 in all ER $\beta$-containing dendrites as well as ER $\beta$-containing dendrites of different sizes (i.e., small vs large) in the experimental groups was determined by specifically designed quantitative dual-labeling EM methods (Milner et al., 2011). For this analysis, the distribution of GluN1 SIG particles in 50 randomly selected dendrites per mouse, rather than in the number of dendrites per mouse, is determined. The number of SIG particles then was calculated per $\mu \mathrm{m}$ of membrane (on and near plasma membrane) or per $\mu \mathrm{m}^{2}$ (cytoplasmic and total) for each dendrite. Inferred in this analysis are corrections for errors related to spatial location, since dendritic profiles within each section are collected from a single plane, as well as differences in dendritic area. Two-way ANOVA followed by a Tukey post hoc analysis was used to compare GluN1 SIG particle density in $\mathrm{ER} \beta$-containing dendrites between groups.

NMDA currents in PVN neurons. NMDA currents were compared between Veh ( $N=3$ mice; $n=6$ slices) and DPN ( $N=3$ mice; $n=4$ slices) in slices from VCD-injected females. A Welch-corrected Student's $t$ test was used for comparison between groups.

ROS production in PVN neurons. First, ROS production following $\operatorname{NMDA}(3,10,30,100$, and $300 \mu \mathrm{M})$ was analyzed in PVN ER $\beta$ neurons from VCD female mice infused with Sal $(N=6 ; n=60$ cells $)$ or AngII $(N=6 ; n=124$ cells) and coadministered either Veh ( $N=3$ /group; $n=63$ cells) or DPN ( $N=3$ /group; $n=185$ cells). One-way repeated-measures 
ANOVA followed by a post hoc multiple Bonferroni comparison test was used to analyze the data. Second, ROS production following NMDA $(3,10,30,100$, and $300 \mu \mathrm{M})$ was measured in $\mathrm{ER} \beta$-containing PVN cells from VCD female reporter mice infused with AngII and coadministered either Veh or DPN (Ang/Veh; $N=3 ; n=38$ cells; Ang/DPN; $N=3$; $n=35$ cells). One-way repeated-measures ANOVA followed by a post hoc multiple Bonferroni comparison test was used to analyze the data.

NMDA currents in PVN neurons after ER $\beta$ blockade. NMDA currents were measured from $\mathrm{ER} \beta$ PVN neurons in PVN slices from normal female $\operatorname{ER} \beta$-GFP reporter mice in the absence $(N=3 ; n=39)$ and presence ( $N=5 ; n=44$ cells) of PHTPP, a full ER $\beta$ antagonist with a 36fold selectivity for $\operatorname{ER} \beta$ over ER $\alpha$ (Compton et al., 2004). A Student's $t$ test was used to compare groups.

ROS production in PVN neurons following ER $\beta$ blockade. ROS production following NMDA $(3,10,30,100$, and $300 \mu \mathrm{M})$ was measured from isolated $\mathrm{ER} \beta$-EGFP PVN neurons from normal female ER $\beta$-GFP reporter mice in the absence $(N=3 ; n=39)$ and presence $(N=5 ; n=44$ cells) of PHTPP. ROS production following NMDA also was measured in isolated $\mathrm{ER} \beta$-EGFP PVN neurons from male $\mathrm{ER} \beta$-GFP reporter mice in the absence $(N=3 ; n=44)$ and presence $(N=3 ; n=49$ cells $)$ of PHTPP. Repeated-measures ANOVA followed by a post hoc multiple Bonferroni comparison test was used to analyze the data.

NMDA $(100 \mu \mathrm{M})$-induced ROS production was measured from AngII-administered female young mice following PHTPP $(N=3$ per group; $n=14$ cells) and using gp91-ds peptide and its scrambled peptide ( $N=2$ per group, $n=14$ cells). One-way repeated-measures ANOVA was performed followed by post hoc Tukey.

SBP following PVN ER $\beta$ deletion. First, SBP was measured in $\mathrm{fER} \beta$ mice that had received unilateral injections of either rAAV-Cre (female $N=4$; male $N=5$ ) or rAAV-GFP (female $N=3$; male $N=3$ ) A Two-way ANOVA following post hoc Tukey was used to compare SBP between males and females before and after vector injections. Second, SBP was measured in $\mathrm{fER} \beta$ mice that had received unilateral injections of either rAAV-Cre (female $N=6$; male $N=5$ ) or rAAV-GFP (female $N=5$; male $N=3$ ) and implanted with osmotic mini-pumps containing AngII. Third, SBP was measured in $\mathrm{fER} \beta$ mice that received a bilateral injection of rAAV-Cre (female $N=4$; male $N=3$ ) or rAAV-GFP (female $N=5$; male $N=3$ ) and implanted with osmotic mini-pumps containing AngII. A Two-way repeated-measures ANOVA followed by post hoc Bonferroni was used to compare the SBP over three time points in animals implanted with osmotic mini-pumps.

The number of $\mathrm{ER} \beta$-labeled nuclei was counted in $\mathrm{fER} \beta$ mice that had received unilateral injections of either rAAV-Cre or rAAV-GFP. Two-way ANOVA followed by a Tukey post hoc analysis was used to compare the ratio of $\mathrm{ER} \beta$-labeled nuclei on the ipsilateral versus contralateral PVN between groups. Nissl cell density ratios between rAAV-Cre and rAAV GFP were also analyzed in unilaterally injected mice using two-way ANOVA to confirm no vector effects on non-ER $\beta$-labeled densities. Separate groups of female and male mice that received bilateral microinjections of vectors were analyzed using a Student's $t$ test to compare vector effects on the total $\operatorname{ER} \beta$-labeled nuclei.

\section{Results}

\section{Cyclic administration of ER $\beta$ agonists attenuates AngII} hypertension in peri-AOF mice

To investigate the effect of $\operatorname{ER} \beta$ agonist administration on AngII hypertension in peri-AOF mice, female $\mathrm{WT}$ and $\mathrm{ER} \beta$ reporter mice were injected with VCD (Fig. $1 A$ ) to induce AOF. Before hypertensive treatment, SBP was recorded in peri-AOF females and then mice were implanted with osmotic mini-pumps containing BSA in saline alone (Sal) or with AngII. Blood pressure was then measured at 7 and $13 \mathrm{~d}$ after pump implantation. Mice were also coadministered vehicle (Veh) or an ER $\beta$ agonist every 2-3 d (Fig. 1B). Aged-matched male WT mice were similarly tested for blood pressure, implanted with mini-pumps, and injected with $\operatorname{ER} \beta$ agonists.
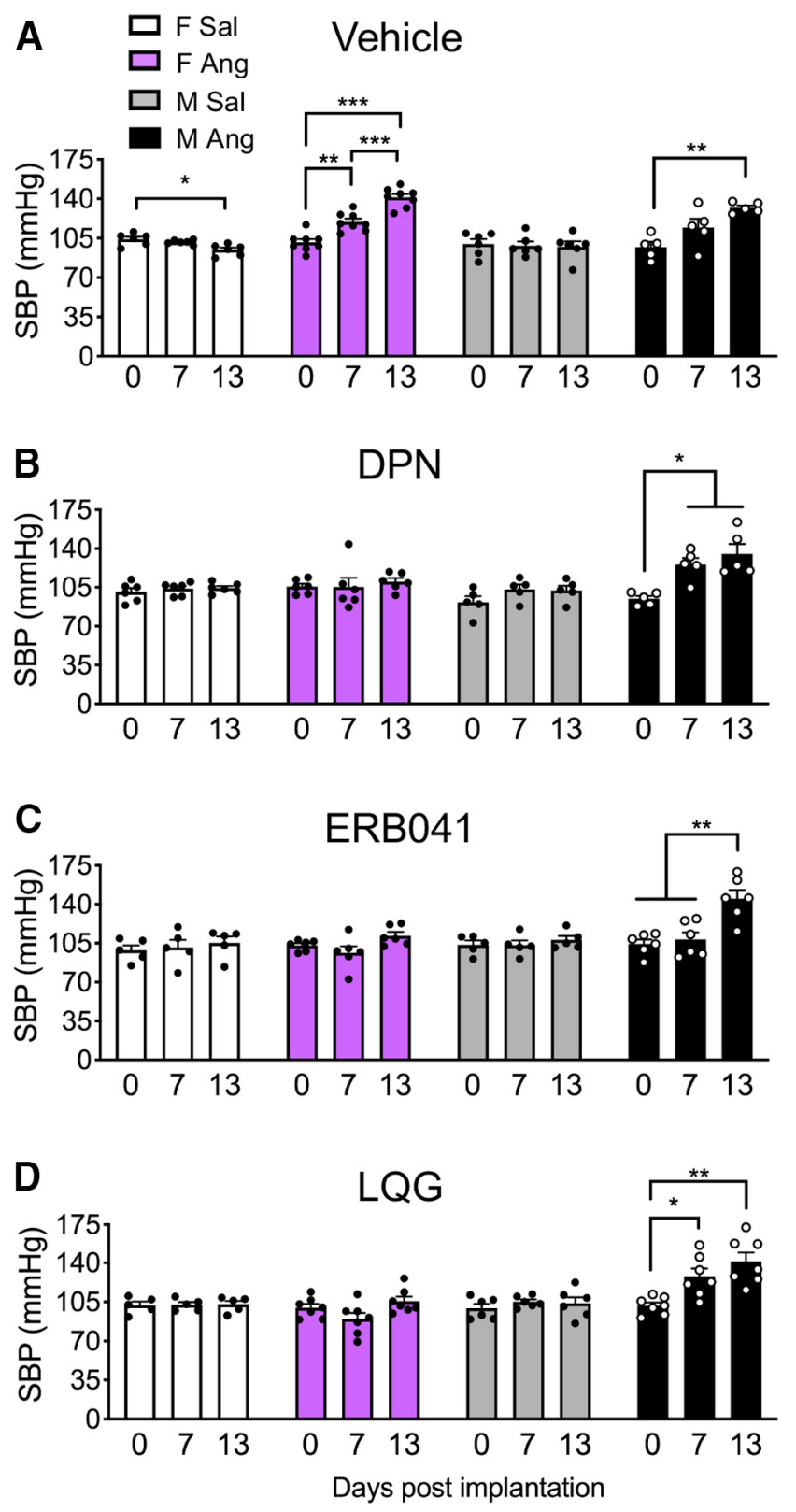

Figure 2. SBP in VCD injected female mice and age-matched male mice infused with slow-pressor Angll and coadministered vehicle or one of three ER $\beta$ agonists. A, VCD female and age-matched male mice given Angll and coadministered vehicle (saline) show an increase in SBP (purple bars and black bars, respectively). $\boldsymbol{B}-\boldsymbol{D}$, After coadministration of DPN, EB-041, or LQG, VCD female mice do not show increased SBP (purple bars). In contrast, males remained hypertensive. Vehicle: F Sal $(N=6), F$ Ang $(N=8)$, M Sal $(N=6)$, M Ang $(N=8)$. DPN: F Sal $(N=6), F$ Ang $(N=9)$, M Sal $(N=5)$, M Ang $(N=6)$. ERB041: F Sal $(N=5)$, F Ang $(N=6)$, M Sal $(N=5)$, M Ang $(N=6)$. LQG: F Sal $(N=5)$, F Ang $(N=7), M$ Sal $(N=6), M$ Ang $(N=7)$. ${ }^{*} p<0.05 ;{ }^{* *} p<0.01 ;{ }^{* * *} p<0.001$; repeated-measures ANOVA. Data are mean \pm SEM.

When infused with Sal and injected with Veh (Sal/Veh), SBP did not increase from days 0 to 13 in VCD females and males (Fig. 2A). However, repeated-measures ANOVA showed SBP was significantly elevated following AngII infusion and Veh injection (Ang/Veh) in VCD females $\left(F_{(1.72,11.98)}=52.10\right.$; $p<0.0001)$ and males $\left(F_{(1.32,5.29)}=12.09 ; p=0.012\right)$, consistent with earlier studies (Van Kempen et al., 2015; Marques-Lopes et al., 2017). VCD-treated Ang/Veh females showed a significant increase in SBP at $7 \mathrm{~d}(p=0.0055)$ and $13 \mathrm{~d}(p=0.0001)$ compared with $0 \mathrm{~d}$, as well as $13 \mathrm{~d}$ compared with $7 \mathrm{~d}(p=0.0006)$. In 
contrast, SBP did not increase in the Ang-VCD females that received DPN, ERB-041, or LQG ( $p>0.05$; Fig. 2B-D). Cyclic administration of DPN, ERB-041, or LQG to Sal VCD females in the absence of AngII did not affect SBP at any time point (Fig. $2 B-D$ ). Thus, cyclic administration of all three classes of ER $\beta$ agonists attenuated AngII-induced hypertension in peri-AOF females.

Similar to Sal-VCD females, DPN, ERB-041, and LQG did not affect SBP at any time point in Sal-treated males (Fig. 2B-D). However, contrary to the AngII-infused VCD female mice coadministered $\operatorname{ER} \beta$ agonists, repeated-measures ANOVA showed SBP was still significantly elevated in AngII-infused male mice coadministered with the following: $\mathrm{DPN}\left(F_{(1.44,5.76)}=13.73 ; p=\right.$ 0.008; Fig. $2 B)$; ERB-041 $\left(F_{(1.7,8.3)}=12.9 ; p=0.0035\right.$; Fig. $\left.2 C\right)$; and LQG $\left(F_{(1.96,11.78)}=13.34 ; p=0.0010\right.$; Fig. $\left.2 D\right)$. Ang/DPN males showed a significant increase in SBP at 13 and $7 \mathrm{~d}$ compared with $0 \mathrm{~d}$ ( $p=0.0346$ and $p=0.0358$, respectively). In addition, Ang/ERB-041 males showed a significant increase in SBP at $13 \mathrm{~d}$ compared with 7 and $0 \mathrm{~d}(p=0.04$ and $p=0.004$, respectively). Further, Ang/LQG males showed a significant increase in SBP at 13 and $7 \mathrm{~d}$ compared with $0 \mathrm{~d}(p=0.0038$ and $p=0.0427$, respectively). In sum, ER $\beta$ agonists reduced SBP in peri-AOF females following AngII, whereas ER $\beta$ agonists were ineffective in AngII-infused males.

\section{The antihypertensive effect of DPN in peri-AOF mice is paralleled by a decrease in plasmalemmal-affiliated GluN1 in ER $\beta$ PVN dendrites}

Sympathetic nervous system activity is strongly implicated in essential hypertension in females (Baker et al., 2016). The PVN is a key site of sympathoexcitatory neurons (Ferguson et al., 2001) and a major locus of $\operatorname{ER} \beta$ neurons in the brain (Milner et al., 2010). The importance of estrogen signaling in the PVN in hypertension in female mice (Marques-Lopes et al., 2017) along with $\mathrm{ER} \beta$ 's critical role in NMDAR plasticity (Sellers et al., 2015 ), suggests that $\mathrm{ER} \beta$ may modulate NMDAR signaling in $\mathrm{ER} \beta$ PVN neurons during hypertension in peri-AOF mice. Given that there is an increase in plasma membrane NMDAR localization, a marker of glutamate plasticity, in $\mathrm{ER} \beta$-containing PVN neurons in peri-AOF mice (Marques-Lopes et al., 2017), we investigated the possibility that $\operatorname{ER} \beta$ stimulation would inhibit surface NMDAR accumulation in these neurons in periAOF mice infused with AngII. Thus, dual-label immuno-EM was used to examine the subcellular distribution of the essential NMDAR subunit GluN1 (labeled by SIG) in GFP (labeled by peroxidase) expressing dendrites in the PVN of $\mathrm{ER} \beta$-GFP reporter mice infused with AngII and cotreated with DPN $(N=3$ mice/condition; $n=50$ dendrites/mouse). Medio-caudal levels of the PVN, which contain numerous ER $\beta$-labeled neurons known to project to the spinal cord (Marques-Lopes et al., 2014; Contoreggi et al., 2021), were selected for analysis (Fig. 3A). GluN1/ER $\beta$-GFP-containing dendrites from Ang/Veh and Ang/DPN peri-AOF and male mice were characterized by their contact with axon terminals forming either symmetric (inhibitory-type) or asymmetric (excitatory-type) synapses (Peters et al., 1991) as well as their aspiny morphology (Fig. 3B-E).

A two-way ANOVA of the subcellular distribution of GluN1SIG in dendritic profiles showed a significant main effect of $\operatorname{sex}\left(F_{(3,597)}=10.01 ; p=0.0016\right)$ and a trending interaction effect of treatment by $\operatorname{sex}\left(F_{(3,597)}=3.73 ; p=0.053\right)$ with respect to particle labeling on the plasmalemma of ER $\beta$-GFP dendrites when examined without consideration of size. Post hoc analysis revealed that Ang/DPN VCD females compared with Ang/DPN males had significantly fewer plasmalemma GluN1-SIG particles $(p=0.002)$ in GFP dendrites (Fig. $3 F)$. Additionally, two-way ANOVA showed a main effect of treatment $\left(F_{(3,597)}=7.43\right.$; $p=0.007)$ as well as an interaction effect between treatment and sex $\left(F_{(3,597)}=4.69 ; p=0.03\right)$ with respect to GluN1-SIG densities near the plasmalemma of these dendrites. Ang/DPN VCD females had significantly fewer GluN1-SIG particles near the plasmalemma compared with Ang/Veh VCD females $(p=0.0032$; Fig. $3 G$ ). Furthermore, two-way ANOVA analysis of GluN1-SIG labeling in the cytoplasm of GFP dendrites showed significant main effects of sex $\left(F_{(3,597)}=23.5\right.$; $\left.p<0.0001\right)$, treatment $\left(F_{(3,597)}=4.48 ; p=0.035\right)$, and an interaction effect between sex and treatment $\left(F_{(3,597)}=13.1 ; p=0.0003\right)$. Ang/Veh VCD females had significantly greater cytoplasmic GluN1-SIG density compared with both Ang/Veh males $(p<0.0001)$ and Ang/DPN VCD females $(p=0.0003 ;$ Fig. $3 H)$. In addition, two-way ANOVA comparison of total GluN1-SIG density showed a significant main effect of treatment $\left(F_{(3,597)}=5.51 ; p=0.02\right)$ and an interaction effect between sex and treatment $\left(F_{(3,597)}=14.5\right.$; $p=0.0002$ ) on GluN1-SIG in GFP dendrites. Ang/Veh VCD females had significantly more total GluN1-SIG compared with Ang/Veh males $(p=0.0005)$ and Ang/DPN VCD females $(p<0.0001$; Fig. 3I).

Larger proximal dendrites are strategically located as an interface between distal dendrites and the cell body and are implicated in intraneuronal integration of inputs from diverse areas of the dendritic tree (Sjöström et al., 2008). Smaller distal dendrites receive a dense innervation of excitatory inputs, contain high levels of excitatory neurotransmitter receptors, and are critical for coordinating excitatory neural transmission (London and Häusser, 2005). Given the functional specialization of these two dendritic compartments, we assessed GluN1 localization in duallabeled dendrites divided into large $(>1 \mu \mathrm{m})$ and small $(<1 \mu \mathrm{m})$ size categories, which corresponds to dendritic distances that are proximal or distal to the cell body, respectively (Peters et al., 1991). In large ER $\beta$-GFP dendrites, two-way ANOVA showed a significant main effect of treatment $\left(F_{(3,149)}=4.595 ; p=0.034\right)$ on the density of GluN1-SIG particles in the cytoplasm. Post hoc analysis revealed Ang/VCD females coadministered DPN had significantly fewer GluN1-SIG particles $(p=0.05)$ in the cytoplasm compared with the Veh coadministered females (not shown).

Small ER $\beta$-GFP dendrites showed the same distribution of GluN1-SIG to that of size-undifferentiated ER $\beta$-GFP dendrites. A two-way ANOVA in small ER $\beta$-GFP dendrites showed significant main effects of $\operatorname{sex}\left(F_{(3,444)}=5.5 ; p=0.02\right)$, treatment $\left(F_{(3,444)}=3.99 ; p=0.05\right)$, and a trending interaction effect of treatment by sex $\left(F_{(3,444)}=3.58 ; p=0.059\right)$ on plasmalemma GluN1 localization. Post hoc Tukey testing confirmed that Ang/ DPN VCD females had a significantly lower GluN1-SIG density on the plasmalemma compared with Ang/DPN males $(p=0.02)$. Post hoc analysis also revealed that Ang/DPN males had significantly higher GluN1-SIG densities on the plasmalemma of small ER $\beta$-GFP dendrites compared with Ang/Veh males $(p=0.03)$ and Ang/Veh VCD females ( $p=0.01$; Fig. $3 J)$. In addition, twoway ANOVA showed main effects of DPN treatment $\left(F_{(3,444)}=\right.$ $7.43 ; p=0.007)$ and an interaction effect of treatment by sex $\left(F_{(3,444)}=5.46 ; p=0.02\right)$ on the density of GluN1-SIG near the plasmalemma. There were also significant main effects of sex in both cytoplasmic GluN1 localization $\left(F_{(3,444)}=22.21 ; p<0.0001\right)$ and total GluN1 labeling $\left(F_{(3,444)}=4.46 ; p=0.04\right)$ as well as a sex by DPN treatment interaction effect with respect to cytoplasmic $\left(F_{(3,444)}=10 ; p=0.001\right)$ and total $\left(F_{(3,444)}=13.03 ; p=0.0003\right)$ GluN1 labeling in small ER $\beta$-GFP dendrites. Ang/Veh VCD 

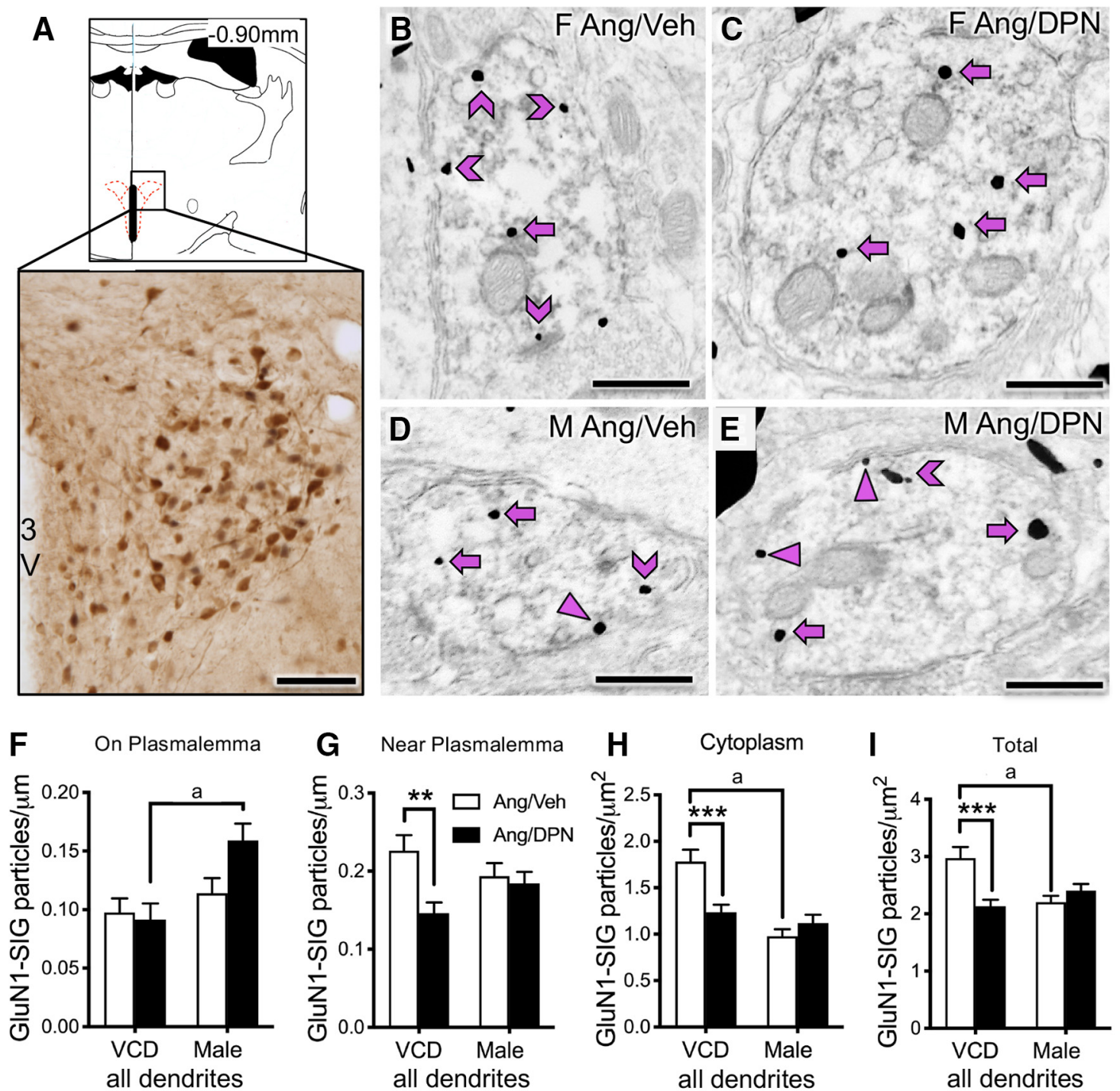

J On Plasmalemma

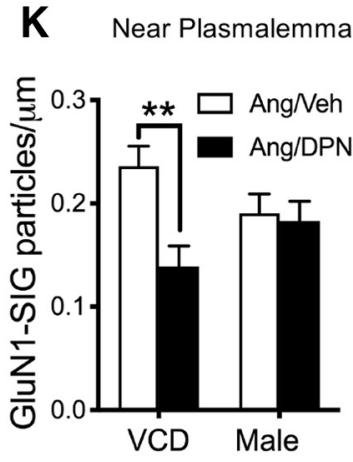

small dendrites
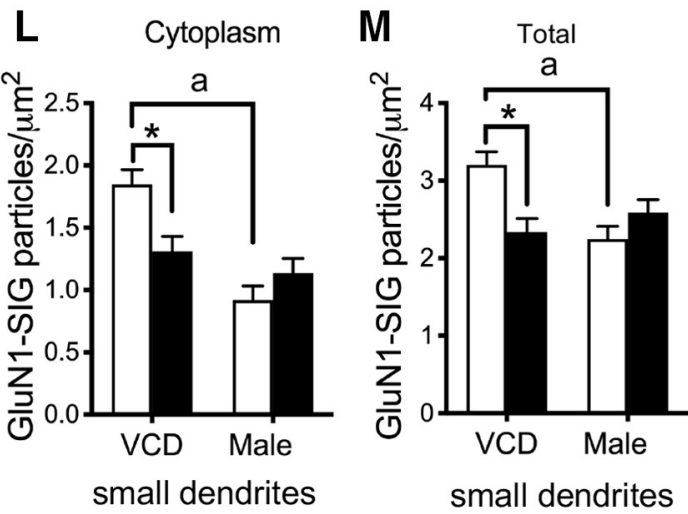

Figure 3. GluN1-SIG densities in ER $\beta$-expressing dendritic profiles of PVN neurons from Angll-infused mice. $\boldsymbol{A}$, Schematic (modified from Hof et al., 2000) and representative light microscopic photograph of ER $\beta$-GFP-labeled neurons in medial region of PVN. 3v, Third ventricle. $\boldsymbol{B}-\boldsymbol{E}$, Representative electron micrographs showing the subcellular localization of GluN1-SIG in ER $\beta$-containing dendrites of Angll-infused VCD-injected female and age-matched male mice coadministered vehicle (saline) or DPN, $\boldsymbol{F}$, VCD-injected female and male mice have similar GluN1SIG densities on the plasma membrane. However, following DPN administration, the GluN1 density in males increases compared with females but not the Veh-administered males. G-I, Administration of DPN to Angll-infused females is associated with significant decreases in near plasmalemmal, cytoplasmic, and total GluN1-SIG particle density in ER $\beta$-containing dendrites. J, In contrast to Ang/DPN VCD females, Ang/DPN males showed a significant increase of GluN1-SIG density on the plasmalemma of small ER $\beta$-GFP dendrites. $\boldsymbol{K}$ - $\boldsymbol{M}$, Ang/Veh VCD females Compared with Ang/Veh males had a significantly greater density of GluN1-SIG particles in the cytoplasm and in total in small ER $\beta$-GFP dendrites. Following DPN administration, Ang VCD females showed a significant decrease in GluN1-SIG densities near plasmalemma, cytoplasmic, and in total in small ER $\beta$-GFP dendrites. Arrow indicates cytoplasm. Triangle represents On PM. Chevron represents Near PM. Scale bars: $\boldsymbol{A}, 100 \mu \mathrm{m} ; \boldsymbol{B}-\boldsymbol{E}, 500 \mathrm{~nm}$. ${ }^{*}, \mathrm{a} p<0.05 ;{ }^{* *},{ }^{a} p<0.01 ;{ }^{* * *},{ }^{a} p<0.001$; two-way ANOVA with Tukey post hoc analysis. $N=3$ mice per group and 50 dendrites per mouse. Data are mean \pm SEM. 


\section{A Females ER $\beta$-EGFP neurons}
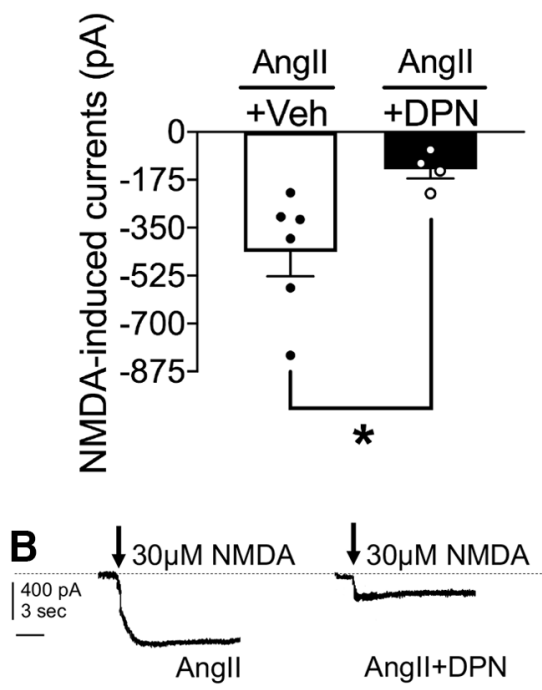

Figure 4. NMDA-induced currents in ER $\beta$-expressing PVN neurons in brain slices of Angll-infused VCD-injected female mice. $A$, Application of NMDA (30 $\mu$ M) results in a depolarization of ER $\beta$-expressing PVN neurons in Angll-infused VCD-injected females $(N=3$; $n=6)$ that is reduced following application of DPN (10 $\mu \mathrm{m} ; N=3 ; n=4)$. $\boldsymbol{B}$, Representative traces from Angll-infused VCD-injected mice show that DPN reduces the amplitude of NMDA currents. ${ }^{*} p<0.05$ (Welch-corrected Student's $t$ test). Calibration: 400 pA, 3 s. Data are mean \pm SEM.

females had a significantly greater GluN1-SIG density compared with Ang/DPN VCD females in near plasmalemma $(p=0.0026)$, cytoplasmic $(p=0.0008)$, and total $(p=0.002)$ GluN1 labeling in small ER $\beta$-GFP dendrites (Fig. $3 K-M$ ). Moreover, compared with Ang/Veh males, Ang/DPN males had significantly more plasmalemmal GluN1 SIG particles in small ER $\beta$-GFP dendrites (Fig. 3J). Also noted, Ang/Veh VCD females had a significantly greater reserve of GluN1-SIG density in the cytoplasm $(p<0.0001)$ and in total $(p=0.0003)$ in small ER $\beta$-GFP dendrites compared with the Ang/Veh males (Fig. $3 L, M$ ).

Collectively, these results show that DPN administered to AngII-infused peri-AOF mice is associated with decreased near plasmalemma GluN1 localization in $\mathrm{ER} \beta$-containing dendritic profiles, suggesting a decrease in the availability of NMDAR for binding by glutamate in $\mathrm{ER} \beta$-expressing PVN neurons.

\section{ER $\beta$ agonist DPN attenuates NMDA-mediated currents in ER $\beta$-expressing PVN neurons of AngII-infused peri-AOF mice}

The reduction in plasma membrane GluN1 associated with DPN administration in AngII-infused peri-AOF mice may be expected to reflect a reduction in AngII-enhanced NMDA currents (Wang et al., 2013; Chen et al., 2017) in ER $\beta$-expressing PVN neurons. Therefore, we next investigated the effect of DPN treatment on NMDA currents in PVN ER $\beta$-GFP neurons from AngII-infused peri-AOF ER $\beta$-EGFP mice using whole-cell patch-clamp recordings in PVN slices. Slices from VCDtreated female mice infused with AngII were treated with Veh $(N=3 ; n=6)$ or DPN $(N=3 ; n=4)$ and NMDA $(30 \mu \mathrm{M})$ currents were recorded. A Welch-corrected Student's $t$ test showed a significant reduction in NMDA currents in $\operatorname{ER} \beta$ EGFP expressing PVN neurons in DPN treated mice relative to Veh $\left(t_{(6.29)}=3.157 ; p=0.02\right.$; Fig. $\left.4 A, B\right)$. Thus, NMDARmediated excitatory responses in PVN ER $\beta$-EGFP neurons from peri-AOF females infused with AngII are significantly attenuated following $\operatorname{ER} \beta$-agonist activation.

\section{Reduced NMDA-induced ROS following DPN in ER $\beta$-expressing PVN neurons of AngII-infused peri-AOF mice}

The production of ROS has been shown to play an important role in the heightened NMDAR signaling seen during hypertension in male mice (Wang et al., 2013; Glass et al., 2015). However, it is not known whether NMDA-induced ROS is elevated in peri-AOF mice following AngII and, if so, whether there is any $\operatorname{ER} \beta$ involvement in heightened ROS following AngII. We next examined NMDA-mediated ROS production using DHE microfluorography (Fig. $5 B, D$ ) in isolated PVN cells from WT VCD-injected female mice infused with AngII. These animals were infused with Sal $(N=6)$ or AngII $(N=6)$ and coadministered either Veh ( $N=3$ /group) or DPN ( $N=3$ /group). Factorial ANOVA showed significant main effects of AngII $\left(F_{(1,428)}=8.6, p<0.004\right)$ and DPN $\left(F_{(1,435)}=8.3, p<0.005\right)$ as well as an AngII by DPN interaction $\left(F_{(1,428)}=34.0, p<0.0001\right)$ with respect to NMDA-induced ROS production. Furthermore, repeated-measures ANOVA showed main effects of NMDA concentration $\left(F_{(5,2140)}=273.3, p<0.0001\right)$ and an interaction effect of AngII by DPN by NMDA concentration $\left(F_{(5,2140)}=16.9, p<\right.$ 0.0001; Fig. 5A,B). Bonferroni post hoc multiple comparisons testing revealed that ROS signal in cells from AngII/Veh $(n=$ $124)$ versus Sal/Veh $(n=60)$ VCD females was higher at NMDA concentrations of $10 \mu \mathrm{M}(p<0.002), 30 \mu \mathrm{M}(p<0.0001), 100 \mu \mathrm{M}$ $(p<0.0001)$, and $300 \mu \mathrm{M}(p<0.0001)$. In addition, ROS-dependent fluorescence in cells from Ang/DPN mice $(n=185)$ was lower compared with those from Ang/Veh mice at all NMDA concentrations $(p<0.0001)$. There were no differences in ROS in cells from Sal/Veh and Sal/DPN $(n=63)$ treated mice across NMDA concentrations.

To verify that ROS reduction by DPN was occurring in $\mathrm{ER} \beta$ expressing cells, NMDA-mediated ROS production was next examined in dissociated EGFP-expressing PVN cells from AngII-infused VCD-injected ER $\beta$-EGFP reporter mice coadministered either Veh $(N=3)$ or DPN $(N=3$; Fig. $5 C, D)$. Factorial ANOVA showed a significant main effect of DPN $\left(F_{(1,71)}=10.1\right.$, $p<0.0025)$. Additionally, repeated-measures ANOVA showed main effects of NMDA concentration $\left(F_{(4,284)}=117.9, p<\right.$ $0.0001)$ and an interaction effect of DPN by NMDA concentration $\left(F_{(2,284)}=5.1, p=0.0005\right)$. Post hoc Bonferroni comparison showed that ROS signal was lower in cells from Ang/DPN $(n=35)$ treated mice compared with Ang/Veh treated mice $(n=38)$, at NMDA concentrations of $30 \mu \mathrm{M}(p<0.03), 100 \mu \mathrm{M}$ $(p<0.0005)$, and $300 \mu \mathrm{M}(p<0.0001$; Fig. $5 C)$.

Collapsed across both experiments, there were main effects of AngII $\left(F_{(1,14)}=5.8, p<0.04\right.$, factorial ANOVA $), \operatorname{DPN}\left(F_{(1,14)}=\right.$ 5.7, $p<0.04$, factorial ANOVA), and an AngII by DPN interaction $\left(F_{(2,16)}=4.7, p<0.02\right.$, repeated-measures ANOVA) with respect to SBP. As expected, there was an increase in SBP in AngII-infused mice compared with vehicle $(p<0.001-0.002$, Bonferroni's test) which was reduced in AngII-infused mice treated with DPN compared with vehicle at days 7 and $13(p<$ 0.001-0.003, Bonferroni's test; data not shown).

Thus, consistent with our electrophysiological studies, stimulation of $\mathrm{ER} \beta$ by DPN attenuated the NMDA-dependent increase in ROS production seen in $\mathrm{ER} \beta$-expressing PVN cells of AngII-infused peri-AOF mice.

\section{ER $\beta$ blockade elevates NMDAR-mediated currents in ER $\beta$-PVN neurons from intact females}

If $\mathrm{ER} \beta$ activity inhibits the elevated NMDA signaling in PVN neurons of AngII administered peri-AOF mice, then blocking 

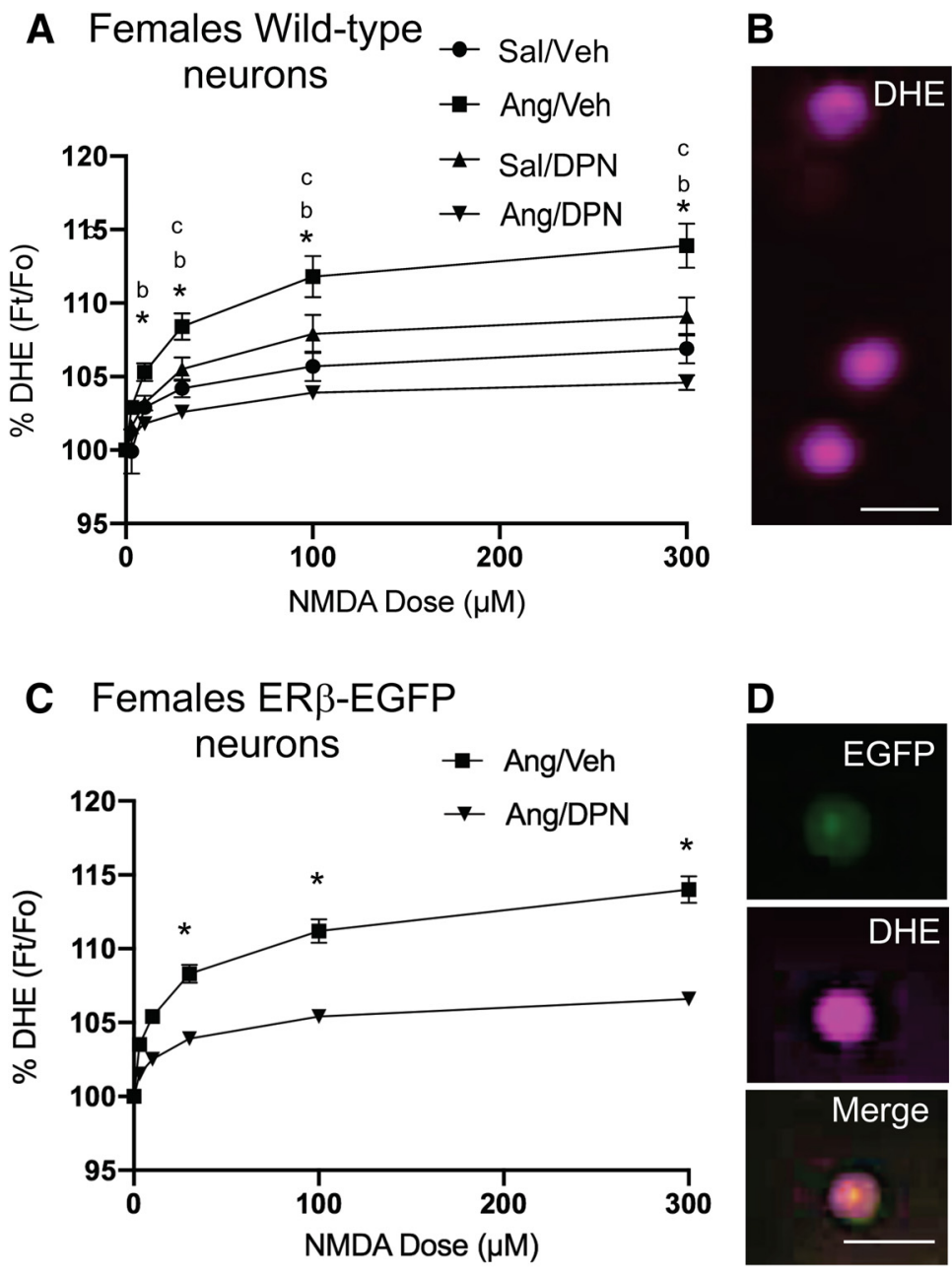

Figure 5. NMDA-mediated ROS production in isolated PVN cells from WT and ER $\beta$-EGFP VCD-injected mice. $\boldsymbol{A}$, Isolated PVN cells from VCD-injected WT mice infused with Angll and then coadministered DPN showed a significant decrease in ROS signal compared with VCD-injected and Angll-infused mice given Veh across NMDA concentrations. There were significant increases in ROS production in cells from Angll versus Veh-infused VCD females at all NMDA concentrations. B, Examples of isolated PVN cells showing ROS-dependent fluorescence with DHE are shown. $\boldsymbol{C}$, Isolated ER $\beta$-EGFP PVN cells of VCD-injected Angll-infused mice show reduced NMDA-mediated ROS signal following DPN administration (Ang/DPN) compared with their vehicle administered counterparts (Ang/Veh). D, Example of an isolated PVN cell showing fluorescence for EGFP, DHE, and merged EGFP/DHE. ${ }^{*} p<0.05$ (factorial and repeatedmeasures ANOVA with post hoc Bonferroni). 'Significance between Sal/Veh versus Ang/Veh. 'Significance between Ang/Veh versus Ang/DPN. Scale bar, $20 \mu \mathrm{m}$. Data are mean \pm SEM.

ER $\beta$ signaling in gonadally intact female mice might be expected to enhance NMDA signaling. To investigate the latter possibility, we examined whether ER $\beta$ blockade would alter NMDA currents in ER $\beta$-EGFP PVN neurons in PVN slices from normal female ER $\beta$-GFP reporter mice. Application of ER $\beta$ antagonist PHTPP ( $1 \mu \mathrm{M} ; N=5 ; n=44)$ in visually identified ER $\beta$-EGFP patched neurons significantly enhanced NMDA currents (Student's $t$ test; $t_{(5)}=6.564, p=0.0012$ ) compared with slices infused with Veh $(N=3 ; n=39)$ (Fig. $6 A, B)$. Thus, selective blockade of $\operatorname{ER} \beta$ resulted in heightened NMDA-mediated currents in $\mathrm{ER} \beta$-expressing PVN neurons in intact female mice.

ROS production increases following ER $\beta$ blockade in ER $\beta$ expressing PVN neurons from intact females

In light of the increase in NMDA currents in PVN ER $\beta$ cells following $\operatorname{ER} \beta$ blockade, we examined whether $\operatorname{ER} \beta$ antagonism would heighten NMDA-dependent ROS production. Thus, the effect of Veh or PHTPP on NMDA-mediated ROS production was investigated by DHE microfluorography in isolated EGFP-expressing PVN cells from intact female ER $\beta$-EGFP mice and male mice. Factorial ANOVA showed a significant main effect of treatment $\left(F_{(1,81)}=6.5, p<0.02\right)$ in females only. ER $\beta$-EGFP PVN cells that were treated with PHTPP $(N=5 ; n=44)$ had a significant increase in NMDA-mediated ROS production compared with those treated with Veh $(N=3 ; n=39 ; \quad$ Fig. $7 A, B)$. Additionally, repeated-measures ANOVA also showed a significant main effect of NMDA concentration $\left(F_{(5,405)}=103.8, p<\right.$ $0.0001)$, as well as an interaction effect of PHTPP by NMDA concentration $\left(F_{(5,405)}=\right.$ $9.4, p<0.0001)$. Signal for ROS was significantly increased at NMDA concentrations of $30 \mu \mathrm{M}(p<0.05), 100 \mu \mathrm{M}(p<0.002)$, and $300 \mu \mathrm{M}(p<0.002)$ in isolated $\mathrm{ER} \beta$-EGFP PVN cells treated with the ER $\beta$ antagonist PHTPP compared with Veh (Fig. $7 A$ ). In contrast to females, PHTPP did not affect the ROS signal at any NMDA concentration in isolated $\operatorname{ER} \beta$ PVN cells from males (not shown). Thus, inhibition of $\operatorname{ER} \beta$ signaling was associated with a significant increase in NMDA-mediated ROS production in $\operatorname{ER} \beta$ expressing PVN cells in female mice.

Given prior reports that NMDA-induced ROS production in male mice is dependent on NOX2 (Wang et al., 2013), we investigated whether NOX2 contributed to ROS production by $\mathrm{ER} \beta$ blockade in $\mathrm{ER} \beta$-EGFP female mice infused with AngII. By one-way repeated-measures ANOVA, it was found that there was an increase in ROS production in isolated $\operatorname{ER} \beta$ EGFP cells after application of PHTPP compared with Veh $(F=3.32, p<0.002, n=14$ cells, $N=3$ mice/per group; Fig. $7 C$ ). Post hoc Tukey's multiple comparisons show that vehicle and PHTPP-treated ER $\beta$ cells had significant increases $(p<0.01)$ in ROS formation following $100 \mu \mathrm{M}$ NMDA. Using the gp91ds peptide as a specific inhibitor of NOX2 and gp91-scrambled peptide as a control, one-way repeated-measures ANOVA comparing vehicle and PHTPP treatment ( $F=5.34$, $p<0.0001, n=15$ cells, $N=2$ mice/per group) followed by post hoc Tukey's multiple comparisons showed that PHTPPenhanced ROS was blocked in the gp91ds group but not in the gp91-scrambled group following $100 \mu \mathrm{M}$ NMDA $(p<0.01$; Fig. $7 D)$. Thus, NOX2 is a source of NMDAinduced ROS production following $\operatorname{ER} \beta$ blockade in $\operatorname{ER} \beta$ containing PVN neurons in female mice infused with AngII.

Deleting ER $\beta$ in PVN neurons increases the susceptibility of gonadally intact female mice to hypertension

If $\mathrm{ER} \beta$ inhibition in PVN neurons contributes to increased NMDAR signaling, then deleting PVN ER $\beta$ in gonadally intact hypertension-resistant female mice might be expected to render them susceptible to hypertension following AngII. We investigated this possibility by deleting $\mathrm{ER} \beta$ selectively in PVN neurons of gonadally intact young female $\operatorname{fER} \beta$ mice. 
Baseline SBP was first assessed in $\mathrm{fER} \beta$ mice followed by microinjection of viral vectors. To delete $\mathrm{ER} \beta$, an rAAV-Cre was unilaterally microinjected into the PVN of female $(N=6)$ and male $(N=5)$ fER $\beta$ mice. In addition, as a vector control, rAAV-GFP was microinjected into the PVN of other groups of female $(N=4)$ and male $(N=3)$ fER $\beta$ mice. After $21 \mathrm{~d}$, mice were tested for SBP. Two-way ANOVA showed an interaction effect of vector and $\operatorname{sex}\left(F_{(1,17)}=17.86 ; p=0.0006\right)$ and a main effect of sex $\left(F_{(1,17)}=7.05 ; p=0.016\right)$ with respect to SBP following unilateral vector injection in the PVN. Post hoc Fisher's analysis revealed a small but significant increase $(\Delta+10.4 \mathrm{mmHg})$ in SBP from baseline in females with $\mathrm{rAAV}$-Cre injection but a significant decrease $(\Delta-11.3 \mathrm{mmHg})$ in SBP from baseline in males with the rAAV-Cre injection ( $p=0.0478$; Fig. $8 A$ ).

Mice were implanted with osmotic mini-pumps containing AngII, and blood pressure was recorded 7 and $14 \mathrm{~d}$ following surgery. With respect to SBP following AngII, two-way repeatedmeasures ANOVA showed there were significant main effects of vector $\left(F_{(5,54)}=p<0.0001\right)$, sex $\left(F_{(1,54)}=6.4, p<0.001\right)$, and a sex by vector interaction $\left(F_{(5,54)}=2.9, p<0.03\right)$. Control female mice injected with rAAV-GFP did not show an increase in blood pressure following AngII at day 7 ( $p>$ $0.26)$ or day $14(p>0.66)$; however, female mice receiving rAAV-Cre responded with a significant increase in blood pressure at day $7(p<0.04)$ and day $14(p<0.01)$ following AngII infusion (Fig. $8 B$ ). In contrast, following AngII, SBP was elevated in male mice receiving either $\mathrm{rAAV}-\mathrm{GFP}$ or $\mathrm{rAAV}$ Cre at day 14 (GFP: $p=0.03$, Cre: $p=0.07$; Fig. 8B).

Following PVN vector microinjection, GFP was expressed in the target site (Fig. $8 C$, top). Levels of $\mathrm{ER} \beta$-labeled cells were quantified as the ratio of ipsilateral to contralateral labeling (Fig. 8C, middle) and two-way ANOVA showed a significant effect of vector in both females and males $\left(F_{(1,18)}=6.3, p<0.0001\right)$. Post hoc testing showed a reduction of PVN ER $\beta$-labeled cells ipsilateral to the microinjection site in both female $(p<0.004)$ and male $(p<$ $0.02)$ mice receiving rAAV-Cre. Moreover, there was no main effect of sex $\left(F_{(1,18)}=\right.$ $0.02, p>0.8)$ or an interaction effect of sex by vector $\left(F_{(1,18)}=1.1, p>0.3\right)$ in the magnitude of $\operatorname{ER} \beta$ reduction between female and male mice receiving the $\mathrm{rAAV}-\mathrm{Cre}$ vector $(p>0.05$; Fig. $8 D)$. We also assessed the density of thionine-labeled cells (Fig. $8 C$, bottom). Two-way ANOVA confirmed that there were no effects of vector $\left(F_{(1,18)}=0.03, p>0.8\right), \operatorname{sex}\left(F_{(1,18)}=0.7 ; p\right.$ $>0.4)$, or interaction of sex by vector $\left(F_{(1,18)}=0.3, p>0.5\right)$ with respect to cell density in female or male mice (Fig. $8 E$ ).

To assess the effect of deleting $\operatorname{ER} \beta$ in both sides of the PVN, separate groups of female mice received bilateral PVN microinjections of rAAV-GFP ( $N=5$ /group) or rAAV-Cre ( $n=4 /$ group). Mice in each group were then infused with AngII and underwent blood pressure testing. An
A Females ER $\beta$-EGFP neurons
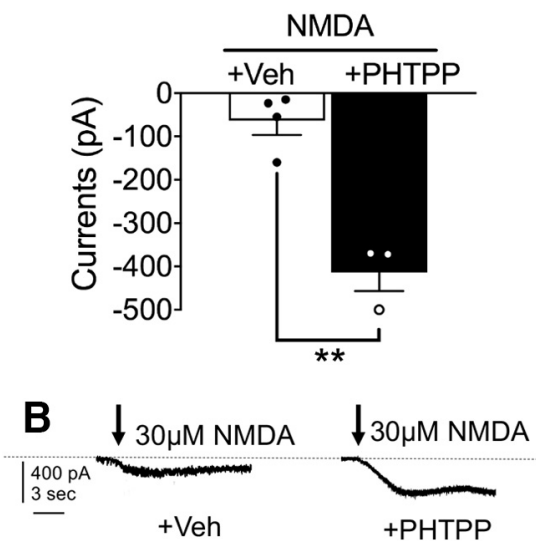

Figure 6. Heightened NMDA-mediated currents following $\operatorname{ER} \beta$ blockade in isolated PVN EGFP cells in females. A, There was an increase in NMDA currents in response to the $\operatorname{ER} \beta$ antagonist PHTPP compared with vehicle in ER $\beta$-EGFP neurons patched from PVN slices. B, Examples of representative currents in PVN slices in response to Veh or PHTPP treatment. ${ }^{*} p<0.05 ;{ }^{* *} p<0.01$; Student's $t$ test. Calibration: 400 pA, 3 s. Data are mean \pm SEM.
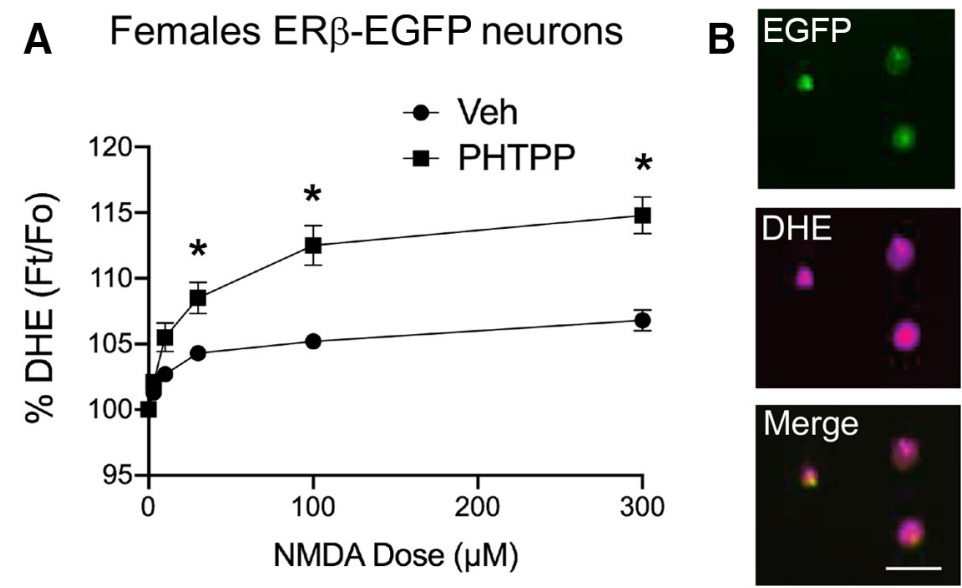

\section{Angll-infused females ER $\beta$-EGFP neurons}

\section{Angll-infused females ER $\beta$-EGFP neurons}
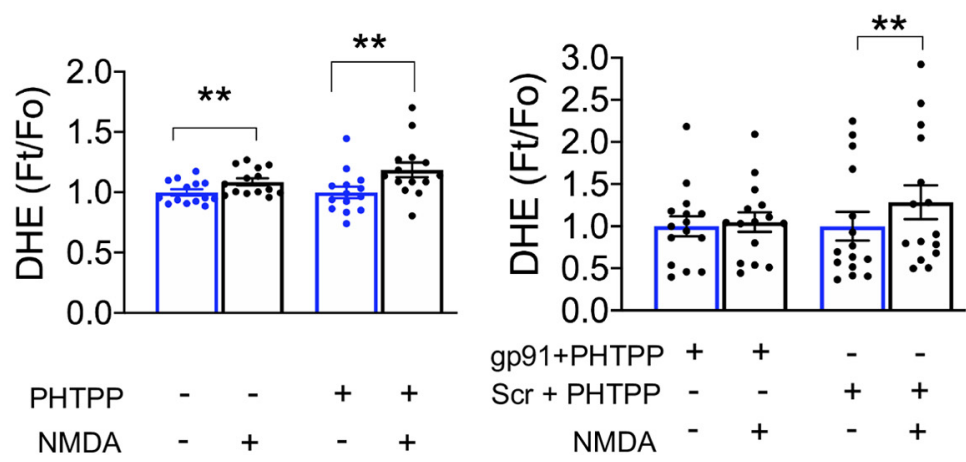

Figure 7. Heightened NMDA-mediated ROS production following ER $\beta$ blockade in isolated PVN ER $\beta$-EGFP cells from Angll-infused females. $\boldsymbol{A}$, In females, ROS production is increased in isolated ER $\beta$-EGFP PVN cells treated with PHTPP compared with their Veh-treated counterparts. $\boldsymbol{B}$, Example of isolated PVN cells from a female mouse showing fluorescence for EGFP, DHE, and merged EGFP/DHE. C, Compared with Veh, application of PHTPP results in a heightened NMDA-induced ROS production in isolated ER $\beta$-EGFP cells. D, PHTPP-enhanced ROS in dissociated ER $\beta$-EGFP PVN cells was blocked by the N0X2 inhibitor gp91ds but not by the gp91 scrambled peptide following $100 \mu \mathrm{m}$ NMDA. C, $D$, The ratio of DHE was calculated as $F_{\mathrm{t}} / F_{0}$, where $F_{\mathrm{t}}$ is DHE fluorescence in a given cell after application of NMDA, and $F_{0}$ is the baseline DHE fluorescence of the same cell immediately before NMDA. ${ }^{*} p<0.05$; ${ }^{*} p<0.01$; factorial and repeated-measures ANOVA followed by Tukey post hoc. Scale bar, $20 \mu \mathrm{m}$. Data are mean \pm SEM. 

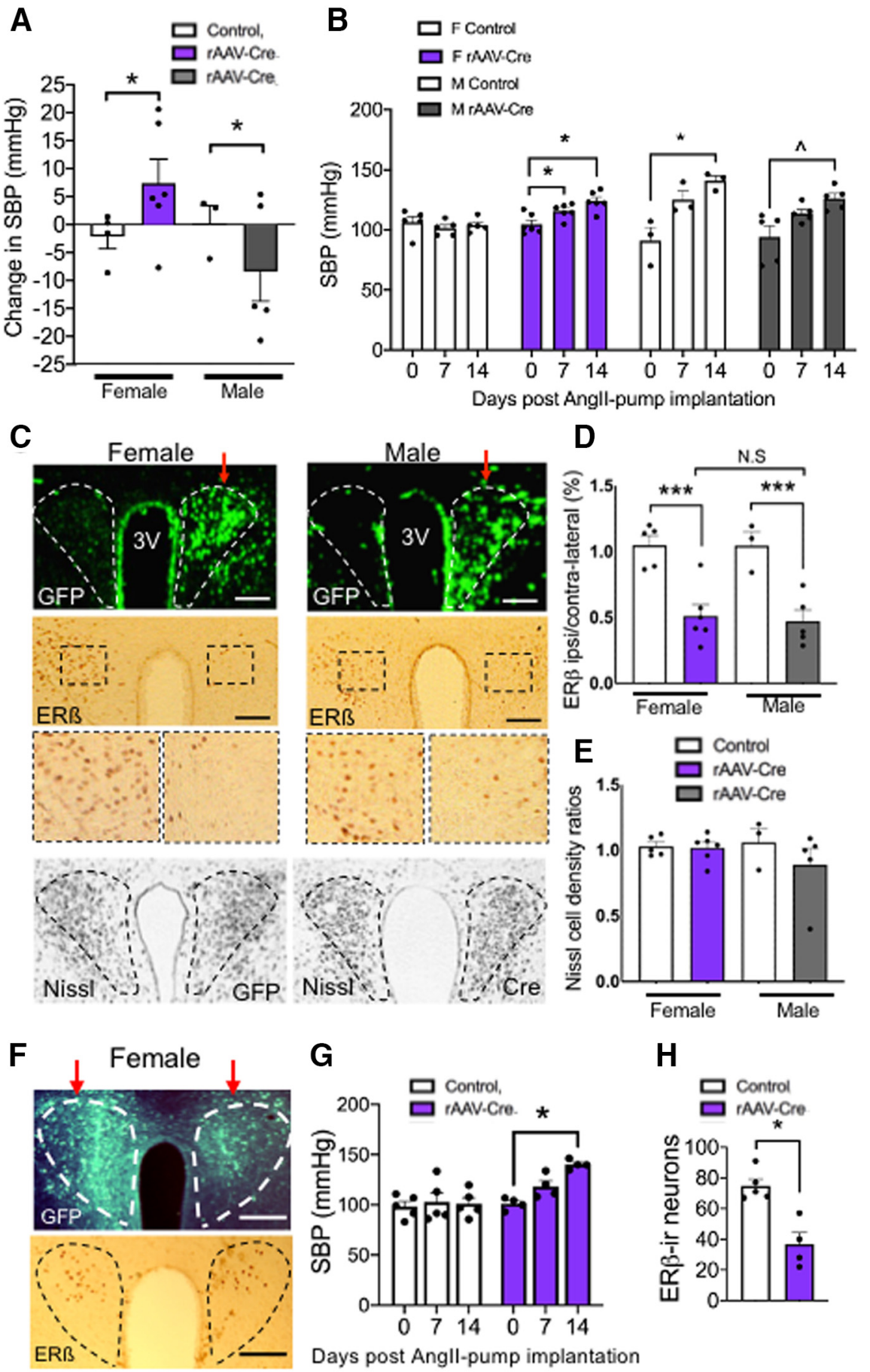

Days post Angll-pump implantation

Figure 8. Spatiotemporal deletion of $E R \beta$ in the PVN of female mice alters SBP at baseline and following Angll infusion. $\boldsymbol{A}$, Unilateral rAAV-Cre microinjection in the PVN was associated with increased SBP in females but decreased SBP in males. $\boldsymbol{B}$, Both female and male mice unilaterally microinjected with rAAV-Cre and infused with Angll showed elevated blood pressure at day 14 relative to baseline. In control microinjected mice, only males showed an increase in SBP. C, Top, Examples of unilateral rAAV-Cre injections (red arrows) in the PVN of female (left) and male (right) fER $\beta$ mice. Middle, Low- and high-magnification examples of $\operatorname{ER} \beta$-labeling in the PVN from the female and male mice shown in the top panel. The number of $\operatorname{ER} \beta$-immunoreactive cells is markedly decreased on the side of the rAAV-Cre injection. Bottom, Examples of Nissl staining in the PVN of rAAV-GFP and rAAV-Creinjected female mice show similar cell densities independent of $\operatorname{ER} \beta$ deletion. $\boldsymbol{D}$, In both males and females, the ratio of $\operatorname{ER} \beta$-immunoreactive cells is significantly reduced in the PVN ipsilateral to the rAAV-Cre (colored bars) injection site, whereas the ratio of $\mathrm{ER} \beta$ is not reduced in the PVN of control animals (white bars). NS, not significant. $\boldsymbol{E}$, Thionin staining shows no significant differences in the ratio of ipsilateral to contralateral cell densities following rAAV-Cre injection. $\boldsymbol{F}$, Examples of labeling for GFP and $\operatorname{ER} \beta$ in the PVN of a female mouse bilaterally microinjected with rAAV-Cre. G, There is an increase in SBP in female mice implanted with osmotic mini-pumps containing Angll and bilaterally microinjected with the rAAV-Cre vector compared with the control vector. $\boldsymbol{H}$, There is a significant decrease in ER $\beta$-labeled neurons in the PVN in bilateral rAAV-Cre-injected female mice compared with control injected female mice shown in $G$. ${ }^{*} p<0.05 ;{ }^{* * *} p<0.0001 ;{ }^{\wedge} p=0.07$; two-way repeated-measures ANOVA followed by Tukey post hoc ( $\boldsymbol{A}, \boldsymbol{B}$ (females), $\boldsymbol{G})$; two-way ANOVA followed by Tukey post hoc (D,E). Data are mean \pm SEM. Scale bars, $0.5 \mathrm{~mm}$. example of GFP and ER $\beta$ labeling following rAAV-Cre microinjection is shown in Figure $8 F$. There was a significant effect of vector $\left(F_{(1,7)}=8.2, p<0.02\right.$, factorial ANOVA) and a vector by time interaction with respect to SBP in bilaterally injected female mice $\left(F_{(2,14)}=7.8, p<0.005\right.$, repeated-measures ANOVA). In rAAV-GFP microinjected mice, there was no difference in SBP at days 7 or 14 relative to baseline $(p>0.05)$, whereas SBP was higher at day 14 relative to baseline ( $p<0.05$, Bonferroni test) in rAAV-Cre microinjected mice (Fig. $8 G)$. In addition, comparison of unilaterally and bilaterally rAAV-Cre-injected female mice showed a greater increase in SBP following AngII in bilaterally compared with unilaterally microinjected animals at day $14\left(t_{(8)}=3.5, p<0.009\right.$, unpaired $t$ test $)$.

Separate groups of male mice $(N=3$ / group) also received bilateral vector microinjections and underwent blood pressure testing after AngII. However, there was no treatment by session interaction with respect to SBP $\left(F_{(2,8)}=0.3, p>0.7\right.$, repeated-measures ANOVA), as SBP was similarly elevated in both groups (not shown).

Labeled ER $\beta$ neurons in the PVN were significantly reduced in female mice receiving rAAV-Cre compared with the control vector $\left(t_{(4.88)}=4.28\right.$; $p=0.008$; unpaired $t$ test; Fig. $8 H)$. In addition, ER $\beta$-labeled neurons were also lower in test vector microinjected male mice $\left(t_{(4)}=2.8, p<0.05\right.$, unpaired $t$ test; data not shown).

In sum, these findings indicate that reduction of $\mathrm{ER} \beta$ expression in PVN neurons renders gonadally intact female mice susceptible to AngII hypertension. Further, these findings suggest that $\mathrm{ER} \beta$ signaling in PVN neurons plays an important role in blood pressure regulation in female mice under both basal and hypertensive conditions.

\section{Discussion}

This study is the first to report that $\mathrm{ER} \beta$ agonist administration is an effective antihypertensive strategy in a mouse model of perimenopausal ovarian decline. It was found that three distinct types of $\operatorname{ER} \beta$ agonist inhibited blood pressure elevation in AngII-infused peri-AOF female, but not male, mice. Moreover, it was also found that AngII was associated with heightened NMDAR signaling and ROS production in PVN ER $\beta$ neurons in post-AOF mice. Further, the increased NMDA signaling in PVN neurons of post-AOF hypertensive mice was 
inhibited by $\operatorname{ER} \beta$ activation. Finally, deleting $\operatorname{ER} \beta$ in PVN neurons of gonadally intact female mice resulted in both AngII hypertension and heightened NMDA signaling. These results provide important evidence that $\mathrm{ER} \beta$ signaling plays an important role in hypertension during early ovarian decline in females. In addition, these findings indicate that $\operatorname{ER} \beta$ signaling in the hypothalamus contributes to NMDAR signaling and blood pressure control in gonadally intact female mice.

We investigated the effect of $\operatorname{ER} \beta$ agonists on AngII hypertension in peri-AOF and male age-matched mice using a cyclic injection schedule that replicates the pulsatile nature of physiological hormone levels (Morrison et al., 2006). With respect to the selection of $\operatorname{ER} \beta$ agonists, a number of agents have been synthesized with varying affinities and potencies (Minutolo et al., 2011), and the results of binding and functional assays have led to the development of a model of three classes of $\operatorname{ER} \beta$ agonists (Leitman et al., 2010). We found that AngII hypertension was inhibited in peri-AOF mice when a representative of each of these classes of ER $\beta$ agonist was administered during AngII infusion. It was also found that each of these agents reduced AngII hypertension to a generally similar extent. In contrast, when coadministered with AngII, none of the $\operatorname{ER} \beta$ agonists affected blood pressure in male mice. Additionally, none of these agents affected blood pressure in Veh administered peri-AOF mice or male mice.

The mechanisms by which estrogen signaling can impact hypertension are not well understood, but actions involving brain systems that regulate blood pressure may play an important role (Van Kempen et al., 2016). Neurogenic processes involving sympathetic nervous system activity are strongly implicated in essential hypertension in females (Baker et al., 2016). The hypertension induced by AngII involves activation of circumventricular-hypothalamic circuits, including a pathway from the subfornical organ to the PVN, a key site of sympathoexcitatory neurons (Ferguson et al., 2001). Significantly, prior anatomic (*Marques-Lopes et al., 2017), physiological (Gingerich and Krukoff, 2006), and gene targeting (Xue et al., 2013) evidence demonstrates that $\mathrm{ER} \beta$ signaling in the $\mathrm{PVN}$ is involved in hypertension.

Prior anatomic studies demonstrate that $\operatorname{ER} \beta$ is expressed in PVN sympathoexcitatory neurons in both male and female rodents (Bingham et al., 2006; Milner et al., 2010). Interestingly, the density of $\operatorname{ER} \beta$-labeled cells does not differ in young male and female mice in areas of the PVN populated by spinally projecting PVN neurons (Milner et al., 2010; Oyola et al., 2017; Contoreggi et al., 2021). This suggests that signaling events downstream of $\operatorname{ER} \beta$ may contribute to sex differences in blood pressure regulation and hypertension. Given evidence that $\operatorname{ER} \beta$ modulates NMDA signaling (Sellers et al., 2015), which is also significantly implicated in AngII hypertension (Zhou et al., 2019), we investigated the role of $\mathrm{ER} \beta$ in NMDAR signaling in the PVN following AngII hypertension.

Dual-labeling EM was used to assess the effect of AngII on NMDAR affiliation with the plasma membrane, indicative of functional receptors, in dendritic profiles of $\mathrm{ER} \beta$-expressing PVN neurons. Consistent with the reduction of SBP in peri-AOF mice following $\operatorname{ER} \beta$ agonist administration, our ultrastructural analysis revealed a significantly reduced GluN1 density near the plasmalemma of dendritic profiles from AngII-peri-AOF mice who received DPN compared with AngII-infused females injected with Veh. These results indicate that the stimulation of $\mathrm{ER} \beta$ by DPN in females contributes to NMDAR transport by retention of the protein in the cytoplasm and away from functional plasma membrane sites in PVN neurons of peri-AOF mice. Interestingly, this effect was strongest in small, presumably distal, dendrites. Given the significance of distal dendrites in receiving and processing excitatory input (London and Häusser, 2005), these results suggest the possibility that $\operatorname{ER} \beta$ may play an important role in inhibiting heightened NMDAR signaling in distal areas of the dendritic tree during hypertension in periAOF mice.

The functional significance of the hypertension-associated alteration in NMDAR localization was further investigated by whole-cell patch-clamping studies. We found that $\mathrm{ER} \beta$-expressing PVN neurons from peri-AOF mice treated with AngII showed an increase in NMDAR currents. Further, this increase in NMDA signaling was suppressed following DPN. These results implicate $\mathrm{ER} \beta$ as an important modulator of NMDARmediated currents that drive the firing rate of PVN neurons in hypertensive peri-AOF mice. Given that many ER $\beta$-expressing neurons project to the spinal cord (Milner et al., 2010; Oyola et al., 2017), these results further suggest that $\operatorname{ER} \beta$-dependent modulation of sympathoexcitatory neurons contributes to the antihypertensive actions of $\operatorname{ER} \beta$ activation in the PVN in periAOF mice.

In addition to suppression of NMDAR signaling, it was also shown that $\operatorname{ER} \beta$ activation inhibited the production of ROS induced by NMDA in isolated ER $\beta$-expressing PVN neurons from hypertensive peri-AOF mice. These results indicate that the sensitivity of female mice to AngII hypertension at periAOF is associated with enhanced NMDA-mediated ROS production in ER $\beta$-expressing cells. Prior reports indicate that ROS production plays an important role in NMDAR signaling in PVN sympathoexcitatory neurons of male mice following AngII hypertension (Wang et al., 2013). Additionally, estrogen, and activation of one of ER $\beta$ 's major effectors Akt, have been previously shown to be associated with reduced ROS and suppressed hypertension in ovariectomized animals (Campos et al., 2014). Importantly, activation of $\operatorname{ER} \beta$ has been reported to be a potent suppressor of ROS production via activation of glutathione peroxidase and superoxide dismutase 2 mediated by an ERK1-2/ $\mathrm{NF} \kappa \mathrm{B}$ pathway (Robb and Stuart, 2011; Lopez-Grueso et al., 2014). Alternatively, scavenging of ROS by nitric oxide may play a role in reduced oxygen radicals in response to estrogen, given evidence that the hormone can elicit increased nitric oxide synthase activity (Campos et al., 2014).

Activation of $\mathrm{ER} \beta$ may influence NDMAR activity and hypertension through genomic or nongenomic actions. Given that the reduced NMDAR currents in our studies occurred in a time frame of minutes, too fast for alterations in gene expression, our results suggest a nongenomic effect of $\operatorname{ER} \beta$ via rapid modulation of intracellular signaling cascades. The contention that $\mathrm{ER} \beta$ is acting via a fast signaling process is consistent with prior reports that estrogen and $\operatorname{ER} \beta$ agonism can rapidly impact NMDAR signaling (Srivastava et al., 2008) via regulation of kinase activity, particularly Akt, a downstream effector of rapid estrogen signaling (Sellers et al., 2015). Specifically, estrogenmediated activation of the Akt pathway in both cerebral cortical synaptosomes (Dominguez et al., 2007) and neurons (Rameau et al., 2007) has been shown to modulate NMDAR phosphorylation, a post-translational receptor modification critical for NMDA plasma membrane trafficking and signaling (Lussier et al., 2015). The activation of the ER $\beta$-Akt pathway has also been shown to play a critical role in neural plasticity, including rapid NMDA-dependent LTP in cerebral cortical neurons (Zang et al., 2020). 
We further investigated the role of hypothalamic $\operatorname{ER} \beta$ in blood pressure in intact mice by deleting $\mathrm{ER} \beta$ in PVN neurons by local delivery of a neurotropic rAAV in age-matched gonadally intact female and male fER $\beta$ mice. We found that deleting $\mathrm{ER} \beta$ in PVN neurons resulted in an increase in blood pressure in female mice infused with AngII. In contrast, AngII-treated male mice with PVN ER $\beta$ deletion did not differ from control injected male mice with respect to hypertension. The latter results are consistent with prior reports showing sex differences in the effects of constitutive ER $\beta$ KO with respect to cardiovascular function (Luksha et al., 2005; Douglas et al., 2008; Gürgen et al., 2011). At the cellular level, we also showed that pharmacological blockade of $\mathrm{ER} \beta$ resulted in an increase in NMDAR currents and NMDA-induced ROS production in $\operatorname{ER} \beta$-expressing PVN neurons in gonadally intact female mice. These results suggest that the vulnerability to hypertension following the suppression of ER $\beta$ signaling in PVN neurons of intact female mice is associated with both heightened NMDAR signaling and ROS production.

In conclusion, the present results demonstrate significant differences in the neural mechanisms of hypertension in peri-AOF female and male mice. In addition, these results also indicate that $\mathrm{ER} \beta$ agonist administration during peri-AOF is an opportune stage for the reduction of hypertension induced by AngII. As hypertension is often comorbid with other diseases that also show sex differences (e.g., Alzheimer's disease), the present findings may have broader implications in the context of aging and blood pressure regulation.

\section{References}

Baker SE, Limberg JK, Ranadive SM, Joyner MJ (2016) Neurovascular control of blood pressure is influenced by aging, sex, and sex hormones. Am J Physiol Regul Integr Comp Physiol 311:R1271-R1275.

Beckerman MA, Glass MJ (2012) The NMDA-NR1 receptor subunit and the mu-opioid receptor are expressed in somatodendritic compartments of central nucleus of the amygdala neurons projecting to the bed nucleus of the stria terminalis. Exp Neurol 234:112-126.

Bedard K, Krause KH (2007) The NOX family of ROS-generating NADPH oxidases: physiology and pathophysiology. Physiol Rev 87:245-313.

Binder AK, Rodriguez KF, Hamilton KJ, Stockton PS, Reed CE, Korach KS (2013) The absence of ER-beta results in altered gene expression in ovarian granulosa cells isolated from in vivo preovulatory follicles. Endocrinology 154:2174-2187.

Bingham B, Williamson M, Viau V (2006) Androgen and estrogen receptorbeta distribution within spinal-projecting and neurosecretory neurons in the paraventricular nucleus of the male rat. J Comp Neurol 499:911-923.

Boudin H, Pelaprat D, Rostene W, Pickel VM, Beaudet A (1998) Correlative ultrastructural distribution of neurotensin receptor proteins and binding sites in the rat substantia nigra. J Neurosci 18:8473-8484.

Brooks HL, Pollow DP, Hoyer PB (2016) The VCD mouse model of menopause and perimenopause for the study of sex differences in cardiovascular disease and the metabolic syndrome. Physiology (Bethesda) 31:250257.

Brose N, Huntley GW, Stern-Bach Y, Sharma G, Morrison JH, Heinemann SF (1994) Differential assembly of coexpressed glutamate receptor subunits in neurons of rat cerebral cortex. J Biol Chem 269:16780-16784.

Burns KA, Rodriguez KF, Hewitt SC, Janardhan KS, Young SL, Korach KS (2012) Role of estrogen receptor signaling required for endometriosislike lesion establishment in a mouse model. Endocrinology 153:39603971.

Butz GM, Davisson RL (2001) Long-term telemetric measurement of cardiovascular parameters in awake mice: a physiological genomics tool. Physiol Genomics 5:89-97.

Campos C, Sartorio CL, Casali KR, Fernandes RO, Llesuy S, da Rosa Araujo AS, Belló-Klein A, Rigatto KV (2014) Low-dose estrogen is as effective as high-dose treatment in rats with postmenopausal hypertension. J Cardiovasc Pharmacol 63:144-151.
Capone C, Faraco G, Anrather J, Zhou P, Iadecola C (2010) Cyclooxygenase 1-derived prostaglandin E2 and EP1 receptors are required for the cerebrovascular dysfunction induced by angiotensin II. Hypertension 55:911-917.

Capone C, Faraco G, Park L, Cao X, Davisson RL, Iadecola C (2011) The cerebrovascular dysfunction induced by slow pressor doses of angiotensin II precedes the development of hypertension. Am J Physiol Heart Circ Physiol 300:H397-H407.

Chen J, Almo SC, Wu Y (2017) General principles of binding between cell surface receptors and multi-specific ligands: a computational study. PLoS Comput Biol 13:e1005805.

Coleman CG, Wang G, Faraco G, Marques Lopes J, Waters EM, Milner TA, Iadecola C, Pickel VM (2013) Membrane trafficking of NADPH oxidase $\mathrm{p} 47$ (phox) in paraventricular hypothalamic neurons parallels local free radical production in angiotensin II slow-pressor hypertension. J Neurosci 33:4308-4316.

Coleman CG, Wang G, Park L, Anrather J, Delagrammatikas GJ, Chan J, Zhou J, Iadecola C, Pickel VM (2010) Chronic intermittent hypoxia induces NMDA receptor-dependent plasticity and suppresses nitric oxide signaling in the mouse hypothalamic paraventricular nucleus. J Neurosci 30:12103-12112.

Compton DR, Sheng S, Carlson KE, Rebacz NA, Lee IY, Katzenellenbogen BS, Katzenellenbogen JA (2004) Pyrazolo[1,5-a]pyrimidines: estrogen receptor ligands possessing estrogen receptor beta antagonist activity. J Med Chem 47:5872-5893.

Contoreggi NH, Mazid S, Goldstein LB, Park J, Ovalles AC, Waters EM, Glass MJ, Milner TA (2021) Sex and age influence gonadal steroid hormone receptor distributions relative to estrogen receptor $\beta$-containing neurons in the mouse hypothalamic paraventricular nucleus. J Comp Neurol 529:2283-2310.

Cvoro A, Paruthiyil S, Jones JO, Tzagarakis-Foster C, Clegg NJ, Tatomer D, Medina RT, Tagliaferri M, Schaufele F, Scanlan TS, Diamond MI, Cohen I, Leitman DC (2007) Selective activation of estrogen receptor-beta transcriptional pathways by an herbal extract. Endocrinology 148:538-547.

Dominguez R, Liu R, Baudry M (2007) 17-Beta-estradiol-mediated activation of extracellular signal regulated kinase, phosphatidylinositol 3-kinase/ protein kinase B-Akt and N-methyl-D-aspartate receptor phosphorylation in cortical synaptoneurosomes. J Neurochem 101:232-240.

Douglas G, Cruz MN, Poston L, Gustafsson JA, Kublickiene K (2008) Functional characterization and sex differences in small mesenteric arteries of the estrogen receptor-beta knockout mouse. Am J Physiol Regul Integr Comp Physiol 294:R112-R120.

Ferguson AV, Washburn DL, Latchford KJ (2001) Hormonal and neurotransmitter roles for angiotensin in the regulation of central autonomic function. Exp Biol Med (Maywood) 226:85-96.

Fernandez-Monreal M, Brown TC, Royo M, Esteban JA (2012) The balance between receptor recycling and trafficking toward lysosomes determines synaptic strength during long-term depression. J Neurosci 32:1320013205.

Gingerich S, Krukoff TL (2006) Estrogen in the paraventricular nucleus attenuates L-glutamate-induced increases in mean arterial pressure through estrogen receptor beta and NO. Hypertension 48:1130-1136.

Girouard H, Wang G, Gallo EF, Anrather J, Zhou P, Pickel VM, Iadecola C (2009) NMDA receptor activation increases free radical production through nitric oxide and NOX2. J Neurosci 29:2545-2552.

Glass MJ, Hegarty DM, Oselkin M, Quimson L, South SM, Xu Q, Pickel VM, Inturrisi CE (2008) Conditional deletion of the NMDA-NR1 receptor subunit gene in the central nucleus of the amygdala inhibits naloxoneinduced conditioned place aversion in morphine-dependent mice. Exp Neurol 213:57-70.

Glass MJ, Wang G, Coleman CG, Chan J, Ogorodnik E, Van Kempen TA, Milner TA, Butler SD, Young CN, Davisson RL, Iadecola C, Pickel VM (2015) NMDA receptor plasticity in the hypothalamic paraventricular nucleus contributes to the elevated blood pressure produced by angiotensin II. J Neurosci 35:9558-9567.

Gürgen D, Hegner B, Kusch A, Catar R, Chaykovska L, Hoff U, Gross V, Slowinski T, da Costa Goncalves AC, Kintscher U, Gustafsson J, Luft FC, Dragun D (2011) Estrogen receptor-beta signals left ventricular hypertrophy sex differences in normotensive deoxycorticosterone acetate-salt mice. Hypertension 57:648-654. 
Haas JR, Christian PJ, Hoyer PB (2007) Effects of impending ovarian failure induced by 4-vinylcyclohexene diepoxide on fertility in C57BL/6 female mice. Comp Med 57:443-449.

Haberstock-Debic H, Wein M, Barrot M, Colago EE, Rahman Z, Neve RL, Pickel VM, Nestler EJ, von Zastrow M, Svingos AL (2003) Morphine acutely regulates opioid receptor trafficking selectively in dendrites of nucleus accumbens neurons. J Neurosci 23:4324-4332.

Harris HA, Albert LM, Leathurby Y, Malamas MS, Mewshaw RE, Miller CP, Kharode YP, Marzolf J, Komm BS, Winneker RC, Frail DE, Henderson RA, Zhu Y, Keith JC Jr (2003) Evaluation of an estrogen receptor-beta agonist in animal models of human disease. Endocrinology 144:42414249.

Harsh V, Schmidt PJ, Rubinow DR (2007) The menopause transition: the next neuroendocrine frontier. Expert Rev Neurother 7:S7-S10.

Hay M, Xue B, Johnson AK (2014) Yes! Sex matters: sex, the brain and blood pressure. Curr Hypertens Rep 16:458.

Hodis HN, Mack WJ (2011) A 'window of opportunity': the reduction of coronary heart disease and total mortality with menopausal therapies is ageand time-dependent. Brain Res 1379:244-252.

Hof PR, Young WG, Bloom FE, Belichenko PV, MR C (2000) Comparative cytoarchitectonic atlas of the C57BL/6 and $129 / \mathrm{Sv}$ mouse brains. Amsterdam: Elsevier.

Kupfer R, Swanson L, Chow S, Staub RE, Zhang YL, Cohen I, Christians U (2008) Oxidative in vitro metabolism of liquiritigenin, a bioactive compound isolated from the Chinese herbal selective estrogen beta-receptor agonist MF101. Drug Metab Dispos 36:2261-2269.

Leitman DC, Paruthiyil S, Vivar OI, Saunier EF, Herber CB, Cohen I, Tagliaferri M, Speed TP (2010) Regulation of specific target genes and biological responses by estrogen receptor subtype agonists. Curr Opin Pharmacol 10:629-636.

Liu N, Wang Y, An AY, Banker C, Qian YH, O’Donnell JM (2020) Single housing-induced effects on cognitive impairment and depression-like behavior in male and female mice involve neuroplasticity-related signaling. Eur J Neurosci 52:2694-2704.

Liu RT, Tang JT, Zou LB, Fu JY, Lu QJ (2011) Liquiritigenin attenuates the learning and memory deficits in an amyloid protein precursor transgenic mouse model and the underlying mechanisms. Eur J Pharmacol 669:76-83.

Lohff JC, Christian PJ, Marion SL, Arrandale A, Hoyer PB (2005) Characterization of cyclicity and hormonal profile with impending ovarian failure in a novel chemical-induced mouse model of perimenopause. Comp Med 55:523-527.

London M, Häusser M (2005) Dendritic computation. Annu Rev Neurosci 28:503-532.

Lopez-Grueso R, Gambini J, Abdelaziz KM, Monleon D, Diaz A, El Alami M, Bonet-Costa V, Borras C, Vina J (2014) Early, but not late onset estrogen replacement therapy prevents oxidative stress and metabolic alterations caused by ovariectomy. Antioxid Redox Signal 20:236-246.

Luksha L, Poston L, Gustafsson JA, Aghajanova L, Kublickiene K (2005) Gender-specific alteration of adrenergic responses in small femoral arteries from estrogen receptor-beta knockout mice. Hypertension 46:1163-1168.

Lussier MP, Sanz-Clemente A, Roche KW (2015) Dynamic regulation of Nmethyl-D-aspartate (NMDA) and $\alpha$-amino-3-hydroxy-5-methyl-4-isoxazolepropionic acid (AMPA) receptors by posttranslational modifications. J Biol Chem 290:28596-28603.

Marques-Lopes J, Van Kempen T, Waters EM, Pickel VM, Iadecola C, Milner TA (2014) Slow-pressor angiotensin II hypertension and concomitant dendritic NMDA receptor trafficking in estrogen receptor beta-containing neurons of the mouse hypothalamic paraventricular nucleus are sex and age dependent. J Comp Neurol 522:3075-3090.

Marques-Lopes J, Lynch MK, Van Kempen TA, Waters EM, Wang G, Iadecola C, Pickel VM, Milner TA (2015) Female protection from slowpressor effects of angiotensin II involves prevention of ROS production independent of NMDA receptor trafficking in hypothalamic neurons expressing angiotensin 1A receptors. Synapse 69:148-165.

Marques-Lopes J, Tesfaye E, Israilov S, Van Kempen TA, Wang G, Glass MJ, Pickel VM, Iadecola C, Waters EM, Milner TA (2017) Redistribution of NMDA receptors in estrogen-receptor-beta-containing paraventricular hypothalamic neurons following slow-pressor angiotensin II hypertension in female mice with accelerated ovarian failure. Neuroendocrinology 104:239-256.
Marques-Lopes J, Van Kempen TA, Milner TA (2018) Rodent models of ovarian failure. In: Conn's handbook of models for human aging (Ram J, ed), Ed 2, pp 831-843. Amsterdam: Elsevier.

Mayer ML, Westbrook GL, Guthrie PB (1984) Voltage-dependent block by $\mathrm{Mg}^{2+}$ of NMDA responses in spinal cord neurones. Nature 309:261-263.

Mayer LP, Devine PJ, Dyer CA, Hoyer PB (2004) The follicle-deplete mouse ovary produces androgen. Biol Reprod 71:130-138.

Mersereau JE, Levy N, Staub RE, Baggett S, Zogovic T, Chow S, Ricke WA, Tagliaferri M, Cohen I, Bjeldanes LF, Leitman DC (2008) Liquiritigenin is a plant-derived highly selective estrogen receptor beta agonist. Mol Cell Endocrinol 283:49-57.

Milner TA, Thompson LI, Wang G, Kievits JA, Martin E, Zhou P, McEwen BS, Pfaff DW, Waters EM (2010) Distribution of estrogen receptor beta containing cells in the brains of bacterial artificial chromosome transgenic mice. Brain Res 1351:74-96

Milner TA, Waters EM, Robinson DC, Pierce JP (2011) Degenerating processes identified by electron microscopic immunocytochemical methods. Methods Mol Biol 793:23-59.

Minutolo F, Macchia M, Katzenellenbogen BS, Katzenellenbogen JA (2011) Estrogen receptor beta ligands: recent advances and biomedical applications. Med Res Rev 31:364-442.

Morrison JH, Brinton RD, Schmidt PJ, Gore AC (2006) Estrogen, menopause, and the aging brain: how basic neuroscience can inform hormone therapy in women. J Neurosci 26:10332-10348.

North American Menopause Society (2017) NAMS 3rd Utian Translational Science Symposium, October 2016, Orlando, Florida. A conversation about hormone therapy: is there an appropriate dose, route, and duration of use? Menopause 24:1221-1235.

Nejat EJ, Chervenak JL (2010) The continuum of ovarian aging and clinicopathologies associated with the menopausal transition. Maturitas 66:187190.

Ovalles AC, Contoreggi NH, Marques-Lopes J, Van Kempen TA, Iadecola C, Waters EM, Glass MJ, Milner TA (2019) Plasma membrane affiliated AMPA GluA1 in estrogen receptor beta-containing paraventricular hypothalamic neurons increases following hypertension in a mouse model of post-menopause. Neuroscience 423:192-205.

Oyola MG, Portillo W, Reyna A, Foradori CD, Kudwa A, Hinds L, Handa RJ, Mani SK (2012) Anxiolytic effects and neuroanatomical targets of estrogen receptor-beta (ERbeta) activation by a selective ERbeta agonist in female mice. Endocrinology 153:837-846.

Oyola MG, Thompson MK, Handa AZ, Handa RJ (2017) Distribution and chemical composition of estrogen receptor beta neurons in the paraventricular nucleus of the female and male mouse hypothalamus. J Comp Neurol 525:3666-3682.

Paxinos G, Franklin KB (2001) The mouse brain in stereotaxic coordinates. San Diego: Academic.

Peters A, Palay SL, Webster HD (1991) The fine structure of the nervous system: neurons and their supporting cells, Ed 3. New York: Oxford UP.

Phan A, Lancaster KE, Armstrong JN, MacLusky NJ, Choleris E (2011) Rapid effects of estrogen receptor alpha and beta selective agonists on learning and dendritic spines in female mice. Endocrinology 152:14921502.

Pierce JP, Kurucz OS, Milner TA (1999) Morphometry of a peptidergic transmitter system: dynorphin B-like immunoreactivity in the rat hippocampal mossy fiber pathway before and after seizures. Hippocampus 9:255276.

Pierce JP, Kievits J, Graustein B, Speth RC, Iadecola C, Milner TA (2009) Sex differences in the subcellular distribution of $\mathrm{AT}(1)$ receptors and NADPH oxidase subunits in the dendrites of $\mathrm{C} 1$ neurons in the rat rostral ventrolateral medulla. Neuroscience 163:329-338.

Pinkerton JV, Stovall DW (2010) Reproductive aging, menopause, and health outcomes. Ann NY Acad Sci 1204:169-178.

Rameau GA, Tukey DS, Garcin-Hosfield ED, Titcombe RF, Misra C, Khatri L, Getzoff ED, Ziff EB (2007) Biphasic coupling of neuronal nitric oxide synthase phosphorylation to the NMDA receptor regulates AMPA receptor trafficking and neuronal cell death. J Neurosci 27:3445-3455.

Reckelhoff JF, Romero DG, Yanes Cardozo LL (2019) Sex, oxidative stress, and hypertension: insights from animal models. Physiology (Bethesda) 34:178-188.

Robb EL, Stuart JA (2011) Resveratrol interacts with estrogen receptor-beta to inhibit cell replicative growth and enhance stress resistance by 
upregulating mitochondrial superoxide dismutase. Free Radic Biol Med 50:821-831.

Rosano GM, Vitale C, Marazzi G, Volterrani M (2007) Menopause and cardiovascular disease: the evidence. Climacteric 10:19-24.

Sahambi SK, Visser JA, Themmen AP, Mayer LP, Devine PJ (2008) Correlation of serum anti-Mullerian hormone with accelerated follicle loss following 4-vinylcyclohexene diepoxide-induced follicle loss in mice. Reprod Toxicol 26:116-122.

Sellers KJ, Erli F, Raval P, Watson IA, Chen D, Srivastava DP (2015) Rapid modulation of synaptogenesis and spinogenesis by 17beta-estradiol in primary cortical neurons. Front Cell Neurosci 9:137.

Shughrue PJ, Merchenthaler I (2001) Distribution of estrogen receptor beta immunoreactivity in the rat central nervous system. J Comp Neurol 436:64-81

Siegel SJ, Brose N, Janssen WG, Gasic GP, Jahn R, Heinemann SF, Morrison JH (1994) Regional, cellular, and ultrastructural distribution of Nmethyl-D-aspartate receptor subunit 1 in monkey hippocampus. Proc Nat Acad Sci USA 91:564-568.

Sjöström PJ, Rancz EA, Roth A, Häusser M (2008) Dendritic excitability and synaptic plasticity. Physiol Rev 88:769-840.

South SM, Kohno T, Kaspar BK, Hegarty D, Vissel B, Drake CT, Ohata M, Jenab S, Sailer AW, Malkmus S, Masuyama T, Horner P, Bogulavsky J, Gage FH, Yaksh TL, Woolf CJ, Heinemann SF, Inturrisi CE (2003) A conditional deletion of the NR1 subunit of the NMDA receptor in adult spinal cord dorsal horn reduces NMDA currents and injury-induced pain. J Neurosci 23:5031-5040.

Srivastava DP, Woolfrey KM, Jones KA, Shum CY, Lash LL, Swanson GT, Penzes P (2008) Rapid enhancement of two-step wiring plasticity by estrogen and NMDA receptor activity. Proc Natl Acad Sci USA 105:14650-14655.

Stuenkel CA, Davis SR, Gompel A, Lumsden MA, Murad MH, Pinkerton JV, Santen RJ (2015) Treatment of symptoms of the menopause: an Endocrine Society Clinical Practice Guideline. J Clin Endocrinol Metab 100:3975-4011.

Suh YH, Terashima A, Petralia RS, Wenthold RJ, Isaac JT, Roche KW, Roche PA (2010) A neuronal role for SNAP-23 in postsynaptic glutamate receptor trafficking. Nat Neurosci 13:338-343.

Sylvester MA, Brooks HL (2019) Sex-specific mechanisms in inflammation and hypertension. Curr Hypertens Rep 21:53.

Tiwari S, Li L, Riazi S, Halagappa VK, Ecelbarger CM (2009) Sex and age result in differential regulation of the renal thiazide-sensitive $\mathrm{NaCl}$ cotransporter and the epithelial sodium channel in angiotensin II-infused mice. Am J Nephrol 30:554-562.

Turner CD, Bagnara JT (1971) General endocrinology. Philadelphia: Saunders.

Van Kempen TA, Milner TA, Waters EM (2011) Accelerated ovarian failure: a novel, chemically induced animal model of menopause. Brain Res 1379:176-187.

Van Kempen TA, Gorecka J, Gonzalez AD, Soeda F, Milner TA, Waters EM (2014) Characterization of neural estrogen signaling and neurotrophic changes in the accelerated ovarian failure mouse model of menopause. Endocrinology 155:3610-3623.

Van Kempen TA, Dodos M, Woods C, Marques-Lopes J, Justice NJ, Iadecola C, Pickel VM, Glass MJ, Milner TA (2015) Sex differences in NMDA GluN1 plasticity in rostral ventrolateral medulla neurons containing corticotropin-releasing factor type 1 receptor following slow-pressor angiotensin II hypertension. Neuroscience 307:83-97.

Van Kempen TA, Marques-Lopes J, Glass MJ, Milner TA (2016) Sex differences in neural regulation of hypertension. In: Hypertension and the brain as an end-organ target (Girouard H, ed), pp 195-221. Cham, Switzerland: Springer.
Volkmann K, Chen YY, Harris MP, Wullimann MF, Koster RW (2010) The zebrafish cerebellar upper rhombic lip generates tegmental hindbrain nuclei by long-distance migration in an evolutionary conserved manner. J Comp Neurol 518:2794- 2817

Wang G, Drake CT, Rozenblit M, Zhou P, Alves SE, Herrick SP, Hayashi S, Warrier S, Iadecola C, Milner TA (2006) Evidence that estrogen directly and indirectly modulates $\mathrm{C} 1$ adrenergic bulbospinal neurons in the rostral ventrolateral medulla. Brain Res 1094:163-178.

Wang G, Coleman CG, Chan J, Faraco G, Marques-Lopes J, Milner TA, Guruju MR, Anrather J, Davisson RL, Iadecola C, Pickel VM (2013) Angiotensin II slow-pressor hypertension enhances NMDA currents and NOX2-dependent superoxide production in hypothalamic paraventricular neurons. Am J Physiol Reg Integr Comp Physiol 304:R1096-R1106.

Waters EM, Mitterling K, Spencer JL, Mazid S, McEwen BS, Milner TA (2009) Estrogen receptor alpha and beta specific agonists regulate expression of synaptic proteins in rat hippocampus. Brain Res 1290:1-11.

Wenger NK (2020) Adverse cardiovascular outcomes for women: biology, bias, or both? JAMA Cardiol 5:253.

Wenger NK, Arnold A, Bairey Merz CN, Cooper-DeHoff RM, Ferdinand KC, Fleg JL, Gulati M, Isiadinso I, Itchhaporia D, Light-McGroary K, Lindley KJ, Mieres JH, Rosser ML, Saade GR, Walsh MN, Pepine CJ (2018) Hypertension across a woman's life cycle. J Am Coll Cardiol 71:1797-1813.

Woods C, Marques-Lopes J, Contoreggi NH, Milner TA, Pickel VM, Wang G, Glass MJ (2021) Tumor necrosis factor alpha-receptor type 1 activation in the hypothalamic paraventricular nucleus contributes to glutamate signaling and angiotensin II-dependent hypertension. J Neurosci 41:1349-1362.

Wright LE, Christian PJ, Rivera Z, Van Alstine WG, Funk JL, Bouxsein ML, Hoyer PB (2008) Comparison of skeletal effects of ovariectomy versus chemically induced ovarian failure in mice. J Bone Miner Res 23:12961303.

Xue B, Pamidimukkala J, Hay M (2005) Sex differences in the development of angiotensin II-induced hypertension in conscious mice. Am J Physiol Heart Circ Physiol 288:H2177-H2184.

Xue B, Zhang Z, Beltz TG, Johnson RF, Guo F, Hay M, Johnson AK (2013) Estrogen receptor-beta in the paraventricular nucleus and rostroventrolateral medulla plays an essential protective role in aldosterone/saltinduced hypertension in female rats. Hypertension 61:1255-1262.

Zang KK, Xiao X, Chen LQ, Yang Y, Cao QL, Tang YL, Lv SS, Cao H, Zhang L, Zhang YQ (2020) Distinct function of estrogen receptors in the rodent anterior cingulate cortex in pain-related aversion. Anesthesiology 133:165-184.

Zhao H, Joseph J, Fales HM, Sokoloski EA, Levine RL, Vasquez-Vivar J, Kalyanaraman B (2005) Detection and characterization of the product of hydroethidine and intracellular superoxide by HPLC and limitations of fluorescence. Proc Nat Acad Sci USA 102:5727-5732.

Zhao H, Kalivendi S, Zhang H, Joseph J, Nithipatikom K, Vasquez-Vivar J, Kalyanaraman B (2003) Superoxide reacts with hydroethidine but forms a fluorescent product that is distinctly different from ethidium: potential implications in intracellular fluorescence detection of superoxide. Free Radic Biol Med 34:1359-1368.

Zhou JJ, Ma HJ, Shao JY, Pan HL, Li DP (2019) Impaired hypothalamic regulation of sympathetic outflow in primary hypertension. Neurosci Bull 35:124-132.

Zitnõanová I, Rakovan $\mathrm{M}$, Paduchová Z, Dvorõáková $\mathrm{M}$, Andrezálová $\mathrm{L}$, Muchová J, Simko M, Waczulíková I, Duračková Z (2011) Oxidative stress in women with perimenopausal symptoms. Menopause 18:12491255 . 